Portland State University

PDXScholar

6-1971

\title{
Age, Emotional Maturity and the Decision to Marry
}

\author{
Patricia Ann Duclos \\ Portland State University \\ David F. Thomas \\ Portland State University \\ Joanne Zusman \\ Portland State University
}

Follow this and additional works at: https://pdxscholar.library.pdx.edu/open_access_etds

Digitairt of the Family, Life Course, and Society Commons, Gender and Sexuality Commons, and the Social Poyemorgy and Interaction Commons

Neetorks know how access to this document benefits you. Logo

\section{Recommended Citation}

Duclos, Patricia Ann; Thomas, David F.; and Zusman, Joanne, "Age, Emotional Maturity and the Decision to Marry" (1971). Dissertations and Theses. Paper 1404.

https://doi.org/10.15760/etd.1403

This Thesis is brought to you for free and open access. It has been accepted for inclusion in Dissertations and Theses by an authorized administrator of PDXScholar. Please contact us if we can make this document more accessible: pdxscholar@pdx.edu. 
AN ABSTRACT OF THE THESIS OF Patricia Ann Duclos, David F. Thomas and Joanne Zusman for the Master of Social Work presented June 11, 1971.

Title: Age, Emotional Maturity and the Decision to Marry.

A PPR OVED BY MEMBERS OF THE THESIS COMMITTEE:

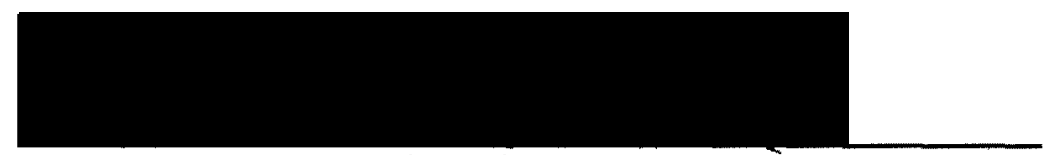

Donald G. Welch, Chairman

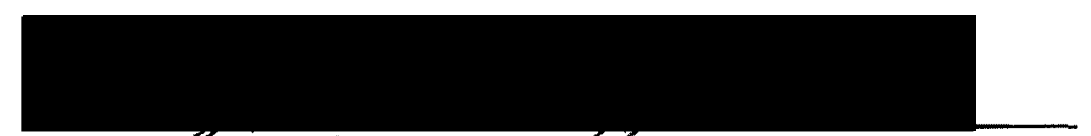

Lyof E. Thompson t5

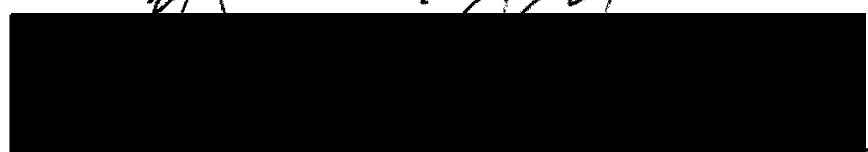

Arthur C. Emlen

The decision to marry and choice of mate are two issues contemplated by most individuals during their lifetime. It is our belief that the manner in which an individual makes these decisions is a reflection of that individual's level of emotional maturity.

In our society, the right to enter into a marriage agreement is largely determined by chronological age. Our research problem began with the hypothes is that there is no direct relationship between chronological age and emotional maturity at the time of marriage.

For our study, marriages were divided into two general categories: 1) teenage marriages in which at least one partner was 20 
years of age or younger, and 2) adult marriages in which one partner was 21 years of age or older. The three independent variables studied were: age, sex of respondent, and sex of spouse. The dependent variable was emotional maturity.

Emotional maturity was operationally defined by a questionnaire consisting of 67 statements about why people decide to marry, and why they chose their particular spouse. A panel of 12 experts in the field of marriage counseling were asked to rate each statement on a seven point scale of maturity-immaturity. The range and mode for each statement was computed and used to construct a new questionnaire consisting of 30 statements. Emotional maturity was defined by the absolute difference between the individual respondent's rating and the expert's modal response.

A sample population was selected using recently married individuals who had applied for marriage licenses in Multnomah County, Oregon. The second questionnaire was mailed to the respondents. A $2 \times 2 \times 2$ factorial design was used to identify which variable or combination of variables accounted for any discrepancy. A multiple regression analysis and a $F$ test were run to test the hypothesis of the study.

The data received supported the null hypothesis. However, there were several conceptual and methodological limitations to the 
study which raise questions as to the reliability of the measuring instrument and use of the concept of emotional maturity. 


\section{AGE, EMOTIONAL MATURITY AND THE}

DECISION TO MARRY

PATRICLA ANN DUCLOS

DAVID F. THOMAS

JOANNE ZUSMAN

A thesis submitted in partial fulfillment of the requirements for the degree of

MASTER OF SOCLAL WORK 
TO THE OFFICE OF GRADUATE STUDIES:

The members of the committee approve the thesis of Patricia Ann Duclos, David F. Thomas and Joanne Zusman presented June $11,1971$.

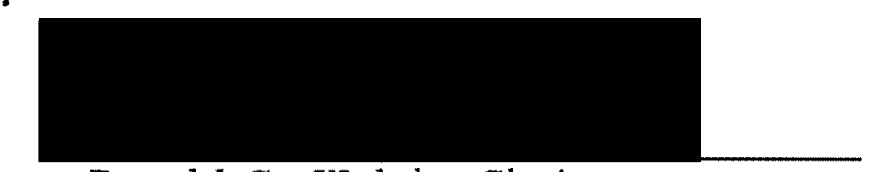

Donald G. Welch, Chairman

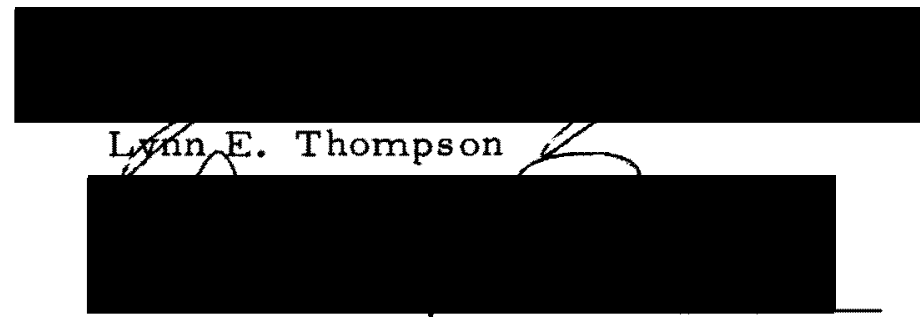

Arthur C. Emlen

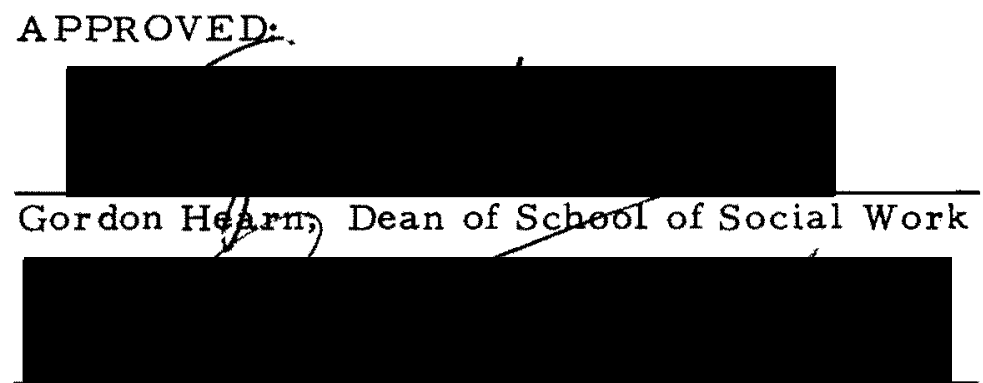

David T. Clark, Dean of Graduate Studies

June $\quad, 1971$ 
TABLE OF CONTENTS

PAGE

LIST OF TABLES . . . . . . . . . . . . . . . vi

LIST OF FIGURES . . . . . . . . . . . . . . . viii

CHAPTER

I INTRODUCTION ............ 1

General Background ........ . 1

Research Problem......... . 3

II REVIEW OF THE LITERATURE . . . . . 5

Effects of Age at Time of Marriage . . . 5

Characteristics of Early Marriage . . 8

Mate Selection ......... 12

Motivation for Marriage . . . . 16

Summary and Hypothesis . . . . . 18

III METHODOLOGY ............ 21

Research Design ........ 21

Panel of Experts . . . . . . . . 24

Questionnaire Rated by Panel of

Experts.......... . 25

Formation of Final Questionnaire . . . 29 
Sample Population . . . . . . 30

Administration and Collection of

Final Questionnaire . . . . . . 34

IV RESULTS . . . . . . . . . . . . 37

Introduction . . . . . . . . . 37

Data from the Experts . . . . . . 38

Data from the Subjects . ... . . . 40

V DISCUSSION OF RESULTS . . . . . . . . . 45

Limitations . . . . . . . . . 45

Implications . . . . . . . . . . 47

Recommendations for Further Study . . 50

BIBLIOGRAPHY . . . . . . . . . . . . . . . . 52

APPENDICES

A EXPERTS' QUESTIONNAIRE . . . . . . 55

B IDENTIFYING CHARACTERISTICS OF PANEL OF EXPERTS . . . . . . . . . 59

C RATIONALE FOR SELECTION PRO-

CEDURE . . . . . . . . . . . . . . 60

D LETTER ENCLOSED WITH

SUBJECTS' QUESTIONNAIRE . . . . . . 63

E SUBJECTS' QUESTIONNAIRE...... .64

F FOLLOW UP LETTER TO SUBJECTS . . . . 67

G EXPERTS' RESPONSES TO

QUESTIONNAIRE . . . . . . . . . . 68 
H SUBJECTS' RES PONSES TO QUESTIONNAIRE . . . . . . . . . . 70

I RESPONSE PATTERN OF SUBJECTS TO ITEMS . . . . . . . . . . . 72

J EMOTIONAL MATURITY SCORES . . . . 73 


\section{LIST OF TABLES}

TABLE

PAGE

Age at Marriage and Divorce . . . . . .

Age at First Marriage for Population

of United States. . . . . . . . . . . .

Independent Variables Treated According

to Teenage or Adult Marriage .......

Distribution of Statements According

to Range

Distribution of Statements According

to Adjusted Range

VI

Distribution of Statements by Modal Value. .

VII

Distribution of Modes in Final

Questionnaire . . . . . . . . . . .

VIII

Eight Categories of Marriage . . . . .

IX

Number of Initial Questionnaires

Returned

$\mathrm{X}$

Number of Aberrant Responses by

Experts 
XI Correspondence between Subjects' and

Experts' Responses . . . . . . . . 42

XII Experts' and Subjects' Modal Responses

to the Questionnaire . . . . . . . . . 43 


\section{LIST OF FIGURES}

FIGURE

PAGE

1

Acceptance Criteria for Modal

Response . . . . . . . . . . . . . .

39

viii 
CHAPTER I

\section{INTRODUCTION}

\section{GENERAL BACKGROUND}

Many young couples, who seek marriage counseling services and are contemplating divorce, make such statements as, "We were just married too young!" These young people seem to have come to the conclusion that their marriages are failing as a direct result of their age at the time they were married. Lee Burchinal, Professor of Sociology at the University of Iowa, has suggested that the young marrieds are treated harshly by institutions such as schools, banks, housing services, and others.

Youth are told that young marriages are hazardous. For various reasons some young persons marry. After marriage, members of the adult community support restrictive policies or refuse to support these young marriages. They find that problems arise, they are compounded and the divorce follows. Then the adults come back and say, 'See, I told you so.' l

Much has been written in regard to the "teenage marriage" and it seems to be a commonly accepted notion in this society that these

${ }^{1}$ Lee Burchinal, "Research on Young Marriage: Implications for Family Life Education," Family Life Coordinator, IX (September 1960), 23. 
marriages tend to end in divorce or separation at a higher rate than marriages of those persons who are over 20 years of age. The importance of age as a factor in the success of marriage is difficult to determine; yet, there must be some age at which we can say an individual is too young to be ready for marriage. "Obviously a child of 12 is not ready to marry. $"{ }^{2}$ In the U.S., every state has a minimum age below which marriage is not allowed. The "magic" age varies from state to state, but in most states the age is 18 for men and 16 for women if they have the permission of their parents. Usually a man must be 21 and a woman 18 before they are free to marry without parental consent.

"The chant of the family textbooks is that 'marriage is for the emotionally mature'. ${ }^{3}$ However, there is great confusion surrounding the concept of emotional maturity. The confusion arises from the fact that the term is so widely used with a variety of connotations. The popular expectation for youthful marriages to fail seems to be based on the assumption that a greater number of those persons under age 21 who marry are emotionally immature in comparison to those persons who are over 21 at the time they marry.

\section{Lester Kirkendall, Too Young to Marry? Public Affairs} Pamphlet No. 236 (Public Affairs Committee, Inc., 1957), p. 2.

${ }^{3}$ Dwight G. Dean, 'Romanticism and Emotional Maturity: A Further Exploration, "Social Forces, XLII (March 1964), 298. 
In our society we are generally alarmed at the large number of marriages which end in divorce courts. Table I, which was adapted from the Bureau of the Census reports, shows the high rate of failure among early marriages. 4

TABLE I

AGE AT MARRIAGE AND DIVORCE

\begin{tabular}{lc}
\hline \multicolumn{1}{c}{ Age at Marriage } & $\begin{array}{c}\text { Percent } \\
\text { Divorced }\end{array}$ \\
\hline Both partners under 20 & 20.2 \\
One under 20, other 20-23 & 14.2 \\
One under 20, other 24 and over & 12.5 \\
Both 20-35 & 10.0 \\
Both 26-30 & 8.7 \\
Both 30 and over & 7.4 \\
\hline
\end{tabular}

II. RESEARCH PROBLEM

Whether to marry, when to marry, whom to marry are decisions nearly everyone in our culture must grapple with at some point in his/her life. These are among the most important decisions one faces in a lifetime. Implications from the literature are: those who marry in their teens are less mature and therefore less capable of making such decisions. However, do teenagers get married for different

${ }^{4}$ Evelyn Millis Duvall, "Student Marriages," Marriage and Family Living, XXII (February 1960), 76. 
reasons than do adults? Do teenagers select a spouse for different reasons? Are there mature versus immature reasons for marrying? Are there mature versus immature reasons for selecting a specific mate? These are the questions which prompted this study. It is the purpose of this study to explore the relationship of emotional maturity to chronological age at time of marriage in regard to the decision to marry and the choice of a mate. 
Much has been written about marriage in sociological, social work, psychological, and anthropological literature. The references reviewed for this study were directly related to: early marriage, divorce, mate selection, and motivations for marriage; as these were the subjects that were of interest to this research group.

\section{EFFECTS OF AGE AT TIME OF MARRIAGE}

The teenage marriage is not a new phenomena. It was the rule rather than the exception until this century. Today, in our increasingly technological society, we are asking for more and more delay of marriage in order that young people may have the opportunity to complete education and be prepared to earn a living prior to marriage."

The median age of the total population of the United States has declined from 30.2 years in 1950 to 27.8 years in $1969 .^{2}$ Even though

${ }^{1}$ Seymour M. Farber, M. D. and Roger H. Wilson, M. D., ed., "Preface," Teenage Marriage and Divorce (Berkeley, California: Diablo Press, 1967), p. iv.

${ }^{2}$ U.S. Bureau of the Census, Statistical Abstract of the U.S., 91 st ed. (Washington, D. C., 1970), p. 23. 
the median age of the population has been declining the median age at first marriage has been climbing and appears to have reached a leveling off stage in recent years. 3

TABLE II

MEDLAN AGE AT FIRST MARRIAGE

FOR POPULATION OF U.S.

\begin{tabular}{llllllllll}
\hline & \multicolumn{8}{c}{ Median Age at First Marriage } \\
\cline { 2 - 9 } Bride & 1940 & 1950 & 1955 & 1960 & 1965 & 1966 & 1967 & 1968 & 1969 \\
\hline \multirow{2}{*}{ Groom } & 21.5 & 20.3 & 20.2 & 20.3 & 20.6 & 20.5 & 20.6 & 20.8 & 20.8 \\
& 24.3 & 22.8 & 22.6 & 22.8 & 22.8 & 22.8 & 23.1 & 23.1 & 23.2 \\
\hline
\end{tabular}

In 1967 Paul Glick, Ph. D. , Assistant Chief of Population

Division of the U.S. Bureau of the Census, and Robert Parke, Jr., a Staff Assistant of the Population Division, wrote about trends in marriage and divorce as seen from the statistics of the U.S. Census. They observed that Americans do marry at an exceptionally young age for an industrial society. The 1960 census showed that among the men who first married at age 18 during the period from 1945 to 1960 , the first marriage was not intact at the time of the census in about 21 percent of all cases. This is twice as high as for men who first married at ages 23 or 24. A similar relationship was evident in the data for

${ }^{3}$ U.S. Bureau of the Census, p. 60. 
females. 4

Age at marriage appears to have an important effect on the likelihood of divorce. The very young marriages, in which the husband or wife was under 20 years of age, seem to be overrepresented in the divorce populations. . . In data for 1950, Glick found that divorce rates were highest in the youngest ages and decreased steadily with age. There were 12.6 divorces per 1000 married females 15 to 19 years of age, but only 2.2 per 1000 married females 45 to 54 years of age. There is no reason to believe that this general relationship has changed since 1950.5

In the late $1940^{\prime}$ s Thomas P. Monahan studied divorce statistics in Iowa. His study included 52,722 marriages and 8, 040 divorces of persons married in Iowa. Monahan's study showed that youthful marriages were over-represented in divorce actions in Iowa. 6

Aside from the objective standards such as divorce and separation rates, which can be used to examine the outcome of young marriages, another set of data which can be used are subjective ratings or evaluations of marriage. In at least five studies a negative relationship has been observed between self-assessed marital happiness ratings and ages at the time of marriage. These studies have

${ }^{4}$ Paul C. Glick and Robert Parke, Jr., "Prospective Changes in Marriage and the Family, "Journal of Marriage and the Family, XXIX (May 1967), 249-256.

${ }^{5}$ Hugh Carter and Alexander Plateris, "Trends in Divorce and Family Dis ruption," Selected Studies in Marriage and the Family, ed. Robert F. Winch and Louis Wolf Goodman (New York: Holt, Rinehart and Winston, Inc., 1968), 570.

${ }^{6}$ Thomas P. Monahan, "Does Age at Marriage Matter in Divorce?" Social Forces, XXXII (October 1953), 81-87. 
shown that there is less satisfaction experienced in a marriage undertaken by persons who marry in the teen years. Persons who married in their teens generally rated their marriages as being less satis factory than persons who married later in life. ${ }^{7}$

\section{CHARACTERISTICS OF EARLY MARRIAGE}

Even though the data do show a relationship between age at marriage and divorce, some researchers feel that there are other factors more relevant than chronological age as the cause for the high divorce rate.

The economic difficulties, the parental dissatisfactions, etc., which rise up to plague the marriages of youthful persons are matters which do not handicap persons marrying after they have attained their legal majority and begin their economic independence. . . . Most important of all it should be realized that forced marriages or marriages whose sole purpose is to establish paternity, are concentrated in the younger ages. To expect marriages begun under such circumstances to show even an average success is not reasonable. When, therefore, we make allowance for this factor, the meaning of the divorce ratios shown in the age at marriage tables is greatly modified. Hence, if we are thinking of marriages of youthful persons, which receive parental approval and such help as is ordinarily extended to newlyweds and which are freely entered into, it appears that youthful marriages may be more hazardous, but that the dangers are much less than these figures roughly indicate. 8

7 Lee Burchinal, "Research on Young Marriage: Implications for Family Life Education," Family Life Coordinator, IX, Autumn (1960), 6-24.

${ }^{8}$ Monahan, Age at Marriage, 83. 
There are differences between early and later marriages implicitly related to age. Earning power and educational achievement are among the more important differences.

Regardless of emotional maturity and the degree of self reliance enjoyed by the couple, younger people cannot have had as much experience in using and reinforcing these adjuncts to successful marriage as have had older people. ${ }^{9}$

Economic difficulty is a major cause of marital breakups for all age groups. It seems that a larger percentage of the younger marriages are burdened with this handicap. However, perhaps these are people who would have financial difficulty in later years regardless of whether they married young.

Although there are higher divorce rates among the youthful marriages, age per se may not be directly to blame. One researcher, Curtis Avery, suggests that society sets up hurdles which make early marriage more difficult than later marriage. High school students are frequently expelled for getting married and if not expelled they may be dropped from honor societies, denied participation in extracurricular activities, and otherwise set apart from unmarried students. Disapproval of early marriage is at every level of our society from the man on the street to the professional who deals with marriage problems every day.

${ }^{9}$ Curtis Avery, "Toward Understanding the Problems of Early Marriage, "Family Life Coordinator, IX, Autumn (1960), 30. 
As we are guilty of disapproving of early marriage because it is more likely to result in divorce, while at the same time by our disapproval, we make such marriages more difficult and more likely to result in divorce, desertion, or separation. 10

One important factor making early marriage a poor $r$ isk is the frequency of premarital pregnancy involved in these marriages. Data from the Bureau of the Census show approximately over one-third to one-half of all young marriages involve premarital pregnancy. 11

A study of adolescent attitudes toward love and marriage was done in high schools across the U.S. by Evelyn Duvall. ${ }^{12}$ Duvall found that a significant relationship existed between not expecting to go through college and being in love with some special person while in school. A significant relationship existed between planning to marry before 21 and not planning to go through college. Teenagers who plan to marry relatively young tend to be those who do not expect to go through college. College-bound teenagers are less often in love while in high school and tend to go steady less than students who are not college-bound. Duvall concluded from this study that being in love as a teenager appears to be an escape hatch for those who feel

10 Avery, 28.

${ }^{11}$ Lee Burchinal, "Trends and Prospects for Young Marriages in the U.S. ", Journal of Marriage and the Family, XXVII (May 1965), 252 .

${ }^{12}$ Evelyn Millis Duvall, "Adolescent Love as a Reflection of Teen-Agers' Search for Identity, " Marriage and Family Living, XXVI (May 1964), $181-190$. 
that other doors to the future are closed. She felt this was especially true for girls who see marriage as a socially acceptable way of establishing themselves as women. Teenagers who expect to go through college get a sense of identity and purpose through their educational aspirations, and so are less inclined to seek a love relationship.

Duvall says that many adolescents regard falling in love and getting married as the way to adulthood; "In their urge to become, they turn too quickly to becoming husbands and wives as an easy answer to their query, 'Who am I?'. "13

In an article for the Journal of Marriage and Family Living, Evelyn Duvall quoted Dr. Clark Vincent of the University of Iowa who studied failure in young marriages. Dr. Vincent believes that the kinds of persons who marry early are less likely to make good marriage partners, and that young marriages involve two persons who may be socially or sexually experienced but emotionally immature. He says that teenagers are not ready to settle down and assume the responsibilities of marriage, and that they are not as adequately prepared for marriage as they are for other careers. 14

\section{${ }^{13}$ Duvall, 190.}

${ }^{14}$ Evelyn Millis Duvall, "Student Marriages," Marriage and Family Living, XXII (February 1960), 76-77. 


\section{MATE SELECTION}

Hollingshead tested theories of mate selection in a study using data from the Department of Vital Statistics of the State of Connecticut in 1948. There were 1,077 couples interviewed in his study. The data presented demonstrated that American culture, as it was reflected in the behavior of these newly married couples, placed very definite restrictions on whom an individual may or may not marry. He saw the community as being divided into pools of marriage mates from which an individual may fish for a mate. Race, religion, ethnic origin, class position, and education all combined to place narrow limits on an individual's choice of a marital partner. ${ }^{15}$

In his doctoral dissertation done at the University of Chicago, Bolton states that the best way to study mate selection is to view it as a process of building a relationship over time. He sees America as a high pressure marriage market. Over 90 percent of Americans marry which indicates that social and personal pressures to marry are extremely heavy. These pressures operate to limit the free market character of mating by pushing the individual toward a choice of mate within the category of persons available to him in his selected

${ }^{15}$ August B. Hollingshead, "Cultural Factors in the Selection of Marriage Mates, "Studies in Marriage and the Family, ed. Robert F. Winch and Louis Wolf Goodman (New York: Holt, Rineholt, and Winston, Inc., 1968), pp. 486-496. 
context during youth. The younger the pers on the more selective his differential association in terms of propinquity, ethnicity, religion, education, and class, and hence the greater the socio-psychological homogeneity of the market within which he chooses. 16

"The question of who marries whom is of perennial interest, but only during the last half century has it become the subject of scientific research. "17 There are many theories of mate selection: the homogamy theory, propinquity theory, parental image theory, complementary needs theory, ideal mate theory, and the value theory.

The homogamy theory holds that an individual tends to choose a marital partner with characteristics similar to oneself. The theory of propinquity is based upon the observed tendency for persons to marry from among those living in spacial proximity. According to psychoanalytic theory a common motive of mate selection is the unconscious wish for a parent substitute. Thus the assumption is made that a person will tend to marry someone with characteristics similar to those of his parent of the opposite sex. Robert Winch formulated the theory of complementary needs, which holds that persons select mates who are similar to themselves in social background characteristics,

${ }^{16}$ Charles D. Bolton, "Mate Selection as the Development of a Relationship, "Marriage and Family Living, XXIII (August 1961), 234-240.

${ }^{17}$ Hollingshead, 486. 
but whose personality structures are complementary to their own. 18 There is also the ideal mate theory which proposes that a young person possesses an image of the kind of person he would like to marry. Coombs refers to a study done by Strauss in 1946 in which about 80 percent of 373 married persons claimed that they had some ideal of a mate and of these a large percentage reported that their ideal had been foremost in their minds when they chose their mates./ Coombs believes that people tend to become similar in values, norms and other cultural aspects with those with whom they interact. It follows that as persons come together in certain areas and begin to participate in common activities they will tend to become more alike in their value systems and behavioral patterns and consequently be more eligible and compatible mates $]$ Coombs goes on to say that his value theory of mate selection is strengthened by Strauss' findings. Fe believes that an ideal mate is merely a visualized combination of all one's basic values projected into an ideal and perfect person. $]^{19}$ I A study of courtship values among 368 married students was done by Smith and Monane at the University of Colorado in 1950. The questionnaire used asked the student to specify in his own words the

${ }^{18}$ Robert F. Winch, Mate Selection (New York: Harper and Brothers, 1958), pp. 88-89.

19 Robert Coombs, "A Value Theory of Mate Selection, "Family Life Coor dinator, X (July 1961), 51-58. 
trait, quality, or characteristic he most desired in a date. On the basis of the specific traits mentioned by the subjects the authors established categories of traits: 1) companionability, which could be congenial, friendly, pleasing personality, etc.;2) desirable physical appearance, which could be good looks, neatness, attractiveness, etc.; 3) social graces, which would be politeness or good manners; 4) intelligence and education; and 5) miscellaneous, such things as good character, sense of humor, maturity, consideration, common interests, social background, etc. The authors found a significant difference between females and males. Women placed little emphas is on desirable physical appearance and stressed traits in the social graces category. Men placed emphasis on desirable physical appearance and did not place much emphasis on social graces. Men placed greater importance than women on traits relating to intelligence and education.] Men were in more agreement with each other on the traits they considered important, while women varied more widely in their specification of desirable traits. Students of different ages varied markedly in their data preferences. Those respondents who were over 23 years old placed little interest in the category of companionability. Those over 23 emphasized a wide variety of traits which fell within the miscellaneous category. 20

20 Eleanor Smith and J. H. Greenberg Monane, "Courtship Values in a Youth Sample, "American Sociological Review, XVIII (December 1953), 635-640. 
Most of the studies in the literature regarding mate selection show differences by sex in what individuals desire in a mate. However, few studies are to be found that deal with the relationship of age to the choice of mate. The literature does not show whether or not there is a major difference in the way in which a teenager selects a mate and the way in which an older person selects a mate.

\section{MOTIVATION FOR MARRIAGE}

"In our society marriage is not as inevitable or as immutable as death but it runs a close second. ${ }^{21}$ Judson Landis believes that social expectancy is a strong force compelling people to marry. Our society has been set up and organized on the assumption that people will marry and establish families. Society looks askance at those who do not marry.

Paul Landis sees modern marriage as a dynamic interrelationship of individuals with personal destinies.

Our much used reason for divorce, mental cruelty, is indicative that marriage is no longer judged in terms of traditional values but by the quality of the interpersonal relationship involved. 22

Landis cites many reasons for marrying. Love, meeting each other's

21 Judson T. and Mary G. Landis, Building a Successful Marriage (New York: Prentice Hall, Inc., 1948), p. 36.

22 Paul H. Landis, Making the Most of Marriage (New York: Meredith Corporation, 1970), p. 13. 
emotional needs, and satisfactory sex relations were mentioned by most couples in a study regarding reasons for marriage. Landis referred to the Strauss study done in 1945 which showed that most persons are dependent on marriage for a share of ego satisfaction. Marriage must, above all things, help both man and wife meet the need for status and recognition. 23

Another study, this one by Duvall and Hill, used a checklist of commonly held reasons for marrying. The subjects were asked to check the two items which would best describe their individual reasons for marrying. The results were that 29.7 percent of the girls checked "desire for companionship"; 25.4 percent checked "to have a home of my own"; 10.9 percent checked "to have children"; 10.8 percent checked "romantic love"; and 9.7 percent checked other reasons such as "social expectations," "economic security, "escape from family," "loneliness," "social status," etc. 24

In both the Strauss and the Duvall and Hill studies subjects most often checked the more "positive" motivations for marriage. Both groups placed strong emphasis on the concept of love.

In an industrial society love of a mate must be recognized as a supreme value for so many as pects of life become competitive that much social experience is the very antithesis of love.

23 Paul H. Landis, pp. 18-27.

${ }^{24}$ Evelyn Millis Duvall and Reuben Hill, When You Marry (New York: Association Press, 1948), p. 110. 
The human being of our time and place on earth must find a love focus that is dependable and sure. In such a world the love marriage is not merely a nice arrangement, it is a necessity. 25

Much has also been written about "negative" motivations for marriage. These are motivations that are disturbing to the marital union: 1) marriage to escape from an unhappy home; 2) marriage to escape from feelings of loneliness; 3) marriage for the purpose of living through the spouse; 4) marriage for material possessions and wealth; 5) marriage to escape the stigma of being unmarried. 26

It should be clear that the impersonality of life in our society imposes serious limitations on the person's ability to appreciate warm and meaningful human associations. Such a way of life inculcates the value of using others as commodities and helps to create a pattern of casual and superficial concern for others which is poor preparation for the heavy emotional commitments that modern marriage requires of a person. Many people enter marriage in the hope that in this relationship they may discover compensation for the empty personal associations of their daily lives. Unfortunately they frequently discover within their marriage the very same qualities of impersonality they wished to avoid. 27

\section{SUMMARY AND HY POTHESIS}

The researchers and writers who concern themselves with early marriage seem to all agree that there is increased risk of failure in

25

Paul H. Landis, p. 26.

${ }^{26}$ Herman R. Lantz and Eloise Snyder, Marriage: An Examination of the Man-Woman Relationship (New York: John Wiley and Sons, Inc., 1969), pp. 85-92.

27

Lantz and Snyder, p. 93. 
marriages contracted when the individuals involved are in their teens.

One explanation for the high rate of failure that appears throughout the literature is that teenagers simply are not sufficiently mature to cope with the heavy responsibilities of marriage.

Readiness for marriage admittedly cannot be determined by chronological age alone. Yet it is difficult to acquire a mature perspective on life without attaining the experience which comes with years. Success in marriage is in part a matter of readiness in the broad sense of having reached the age at which one can fit into life plans and accept and carry the obligations marriage involves. When to marry is the real question and this is answered in terms of one's own development. 'To everything there is a season and a time for every purpose under heaven'. 28

How do we know when a person is ready for marriage? How do we know when he is mature? There are many tests and measures of personality adjustment, emotional and psychological maturity, but we cannot determine an individual's maturity or readiness for marriage by his chronological age.

Mervyn L. Cadwallader, Associate Professor of Sociology at San Jose State College, asks:

Is an adolescent exalted and changed at 16, 18, or 21 ? Our society does not have a conventional rite of passage. Lacking such a clearly defined ceremonial, perhaps it should provide one so as to take the guesswork out of growing up. Does the adolescent become an adult upon passing a driver's test, a drinking test, a sexual test, or domesticity test? The Masai adolescent takes a lion test. He becomes an adult the day he kills a lion with a spear. Our adolescents become men when they kill

28

Paul H. Landis, p. 305. 
Peter Pan at the altar and move into an apartment with a real live wife. 29

The concept of emotional maturity, though used throughout the literature, does not have a commonly accepted definition and is used in many different, and sometimes contradictory, ways. However, there are characteristics which are commonly accepted as being descriptive of emotional maturity. Most frequently used to describe emotional maturity is the concept of decision-making or judgement. The implication is that the mature person makes better decisions.

There are three decisions involved in getting married. One must first decide whether to marry, he/she must also decide whom to marry and when to marry. In this study these decision-making processes are to be used as measures of emotional maturity. The hypothesis to be tested is that there is no direct relationship between emotional maturity and chronological age at the time of marriage. The age of the subject, the sex of the subject, and the age of the subject's spouse are the independent variables, Emotional maturity, as operationally defined for this study, is the dependent variable.

29 Mervyn L. Cadwallader, "In Search of Adulthood," Teenage Marriage and Divorce, ed. Seymour M. Farber and Roger H. Wilson (Berkeley, California: Diablo Press, 1967), p. 15. 
CHAPTER III

\section{METHODOLOGY}

\section{RESEARCH DESIGN}

Our research design began with the null hypothesis that there is no relationship between chronological age and emotional maturity at the time of marriage. We were concerned with emotional maturity in the context of marriage, as it relates to an individual's decision whether to marry, and whom to marry. It was our belief that the level of emotional maturity at which an individual is functioning determines the manner in which these decisions are made.

The independent variables were age, sex of respondent, and sex of spouse. The dependent variable was emotional maturity. It was our intention to look at the independent variables on two levels as shown in Table III on the following page.

Since we could not find a test of emotional maturity that we felt was adaptable to our study, we decided that emotional maturity might possibly be measured by taking items from the literature, and having these items rated by a panel of experts in the field of marriage counseling. A person's level of emotional maturity could then be 
TABLE III

INDE PENDENT VARIABLES TREATED ACCOR DING TO TEENAGE OR ADULT MARRIAGE

\begin{tabular}{llccc}
\hline & Sex & $\begin{array}{c}\text { Age of } \\
\text { Respondent }\end{array}$ & $\begin{array}{c}\text { Age of } \\
\text { Spouse }\end{array}$ \\
\hline Teenage (20 or below) & $M$ & 20 & 19 \\
Adult $\quad(21$ or above $)$ & $F$ & 24 & 22 \\
\hline
\end{tabular}

computed by comparing his score to that of the experts. Emotional maturity was operationally defined by the absolute difference between the individual respondent's rating and the expert's modal response. We decided to construct our own instrument as a means of measurement which was a short questionnaire administered by mail to a sample population.

There were two phases in the development of this questionnaire. The first phase consisted of reviewing the literature and gathering a series of statements reflecting an individual's decision to marry and his choice of mate. To accomplish this we took items from two sources: the first from the six theories of mate selection, and the second a study by Smith and Monane which were discussed in Chapter II. ${ }^{1}$ This process produced 67 statements. These statements were then

${ }^{1}$ Eleanor Smith and J. H. Greenberg Monane, 635-640. 
converted to a series of declarative sentences and presented in questionnaire form.

A scale ranging from one to seven was used to rate the level of maturity reflected in each sentence. The number one on the scale represents a response of "very immature" and the number seven "very mature." We wanted the polar ends of this scale to represent extreme responses. For example, a person rating a sentence as very immature would be saying that the sentence reflects a very immature reas on for either getting married or choosing his s pouse. This particular scale was used because we wanted to allow for a wide range of responses that would reflect all levels of emotional maturity, from very immature to very mature. This questionnaire was submitted to a panel of experts who were asked to rate each statement. A copy of this questionnaire can be found in Appendix A.

The second phase of our questionnaire development consisted of taking the statements, as related by the panel of experts, computing the range and mode for each statement, and using this data to select 30 statements to be used for the subjects' questionnaire. These 30 statements were then converted into questions compiled in questionnaire form, using the same seven point rating scale.

Once the final (subjects') questionnaire was complete, we began locating our sample population. We used recently married individuals who had applied for marriage licenses in. Multnomah 
County, Oregon. The sample consisted of 48 individuals. A small sample was chosen to allow us to follow up on the unreturned questionnaires to achieve as close to 100 percent return as possible.

Once returned, the respondents' questionnaires were scored and the data were used for a statistical analysis. A $2 \times 2 \times 2$ factorial design was used (Table III on page 22) so that we could tell which variable accounts for any discrepancy, or if it is a combination of any two variables. This allowed us to control for both sex and age of the respondent. A multiple regression analysis and a $F$ test were used to test the hypothesis of the study.

\section{PANEL OF EXPERTS}

A panel of experts was selected. Their specific task was to rate each of our 67 declarative sentences according to its maturity or immaturity. Our panel of experts consisted of 12 members, representing three social agencies. Nine members came from the Department of Family Services, two members came from the Delauney Institute, and one member from the Benton County Mental Health Clinic.

These people were all marriage counselors. They were our choice as panel members because they offered a specialized body of knowledge related to marriage. Each panel member had the 
advantage of experience with numerous families in relation to marriage and/or family related problems.

The panel consisted of one Negro and 11 Caucasians. Eight were males and four were females. Their median age was 39.9 years. Their median number of years in counseling was 11.8 years. The median number of years with their specific agency was 5.0 years. The median number of years as a counselor dealing with marriage and/or family related problems was 11.7 years. Ten members have Master's Degrees of Social Work; of these ten, one person also has a $\mathrm{Ph} . \mathrm{D}$. Degree. Two panel members have Baccalaureate Degrees; both of these individuals have graduate hours, one in psychology and the other is currently participating in a graduate degree program in social work. Appendix B provides a more detailed analys is of our panel of experts.

\section{QUESTIONNAIRE RATED BY PANEL OF EXPERTS}

As we analyzed the data from the returned questionnaire we found a wide range of responses on each item. Out of 67 items the range was as shown in Table IV. Only 29 statements out of 67 had a range of 3 or less. This represented 43 percent of the statements. Statement No. 2, "Marriage provides a way out of an unpleasant school experience," was the only item on which the panel agreed. 
TABLE IV

DISTRIBUTION OF STATEMENTS

ACCOR DING TO RANGE

\begin{tabular}{cc}
\hline Range & $\begin{array}{c}\text { Number of } \\
\text { Statements }\end{array}$ \\
\hline 1 & 1 \\
2 & 8 \\
3 & 20 \\
4 & 18 \\
5 & 16 \\
6 & 4 \\
\hline
\end{tabular}

We found a number of extreme responses that were at least one number apart from any other responses. Table $\mathrm{X}$ on page 40 indicates the number of extreme, or aberrant, responses among the panel members.

To account for the extreme responses we discarded the high and low responses for each item. This was done uniformly for all 67 statements, and then the range was recomputed. Table V shows the adjusted range. After recomputing the range, we now had 33 statements with a range of one and two, representing 49 percent of the statements.

There were now four statements with a range of one. In addition to statement No. 2, the remaining three were No. 4 , "Marriage is used to acquire higher economic status"; No. 16, "People marry 'on the rebound' following the breakup of an intimate 
TABLE V

\section{DISTRIBUTION OF STATEMENTS ACCOR DING \\ TO ADJUSTED RANGE}

\begin{tabular}{cc}
\hline Range & $\begin{array}{c}\text { Number of } \\
\text { Statements }\end{array}$ \\
\hline 1 & 4 \\
2 & 29 \\
3 & 24 \\
4 & 9 \\
5 & 1 \\
\hline
\end{tabular}

relationship"; and No. 21, "People marry to escape from an unpleasant work situation." These four statements all had the commonality of presenting marriage as a means of moving from a less desirable situation to a more desirable situation.

Statement No. 47, "I married my spouse because he needed me," was the only item with a range of five.

We next computed the modal score for each statement. The mode was used as the measure of central tendency because it reflects the most frequent response among the experts. This was important because we wanted to select statements that represented various levels of maturity, from very immature to very mature. The mode also provides a weight for each item which represents the level of maturity reflected in that item. This would be used in computing the emotional maturity score (EM score) of our sample population. The EM score is 
the absolute difference between the experts' modal score and the respondents' raw score.

After computing the mode, we found the results as shown in the following table.

TABLE VI

DISTRIBUTION OF STATEMENTS

BY MODAL VALUE

\begin{tabular}{lc}
\hline Mode & $\begin{array}{c}\text { Number of } \\
\text { Statements }\end{array}$ \\
\hline 1.5 & 3 \\
1.5 & 2 \\
2 & 16 \\
2.5 & 1 \\
3 & 13 \\
3.5 & 2 \\
4 & 11 \\
4.5 & 1 \\
5 & 12 \\
5.5 & 2 \\
6 & 3 \\
6.5 & 0 \\
7 & 1 \\
\hline
\end{tabular}

An analysis of these data reveals that 33 percent $(.3283)$ of the statements were considered immature, 58 percent $(.5820)$ were considered average, and 9 percent (.0895) were considered mature. 
It can be seen that the statements, as rated by the experts, were weighted in the direction of emotionally immature.

The three statements considered the most immature were No. 9 , "Men marry to avoid the draft"; No. 16, "People marry 'on the rebound' following the breakup of an intimate relationship"; and No. 29, "People marry to escape from an unhappy home situation." Statement No. 56, "I married my spouse because we can communicate!" was the only item considered very mature.

\section{FORMATION OF FINAL QUESTIONNAIRE}

Our next task was to take the statements rated by our panel of experts and convert them into questions to be presented to our sample population. We wanted questions with less deviations, thereby increasing the reliability of our scale. We also wanted the length of the final questionnaire to be 30 questions. This size could be presented in three pages, complete with instructions so that the respondent's attention could be held and the questionnaire could be mailed for six cents.

We considered both the range and mode of each statement as criteria for making our selection. All statements with a range of one and two were automatically selected because they reflected high agreement among the experts. A statement with a range of one or two meant at least ten experts were in close agreement about the level of 
emotional maturity reflected by that statement after the aberrant responses were eliminated. By using these statements we were able to maintain consistency within the final questionnaire.

The final questionnaire consisted of 30 questions. Twenty-two had a range of one and two; seven had a range of three, and one had a range of four.

We were also concerned about the modal score because we wanted our final questionnaire to reflect statements from various levels of maturity. The following table (Table VII) shows the distribution of modal scores in the final questionnaire. Appendix $C$ provides a detailed analysis of the selection procedure involved in reducing the 67 statements from the experts' questionnaire to the final 30 questions on the respondents' questionnaire.

\section{SAMPLE POPULATION}

We were interested in comparing two groups of marriages, teenage and adult. We defined a teenage marriage as a marriage in which either partner is under the age of 21 . We took into consideration the fact that in this society, in most instances, 21 is recognized as the age of majority. For example, in most states 21 is the age at which one is allowed to vote, serve on a jury, purchase liquor, and the age at which a man may marry without his parents' consent. 
TABLE VII

DISTRIBUTION OF MODES IN FINAL QUESTIONNAIRE

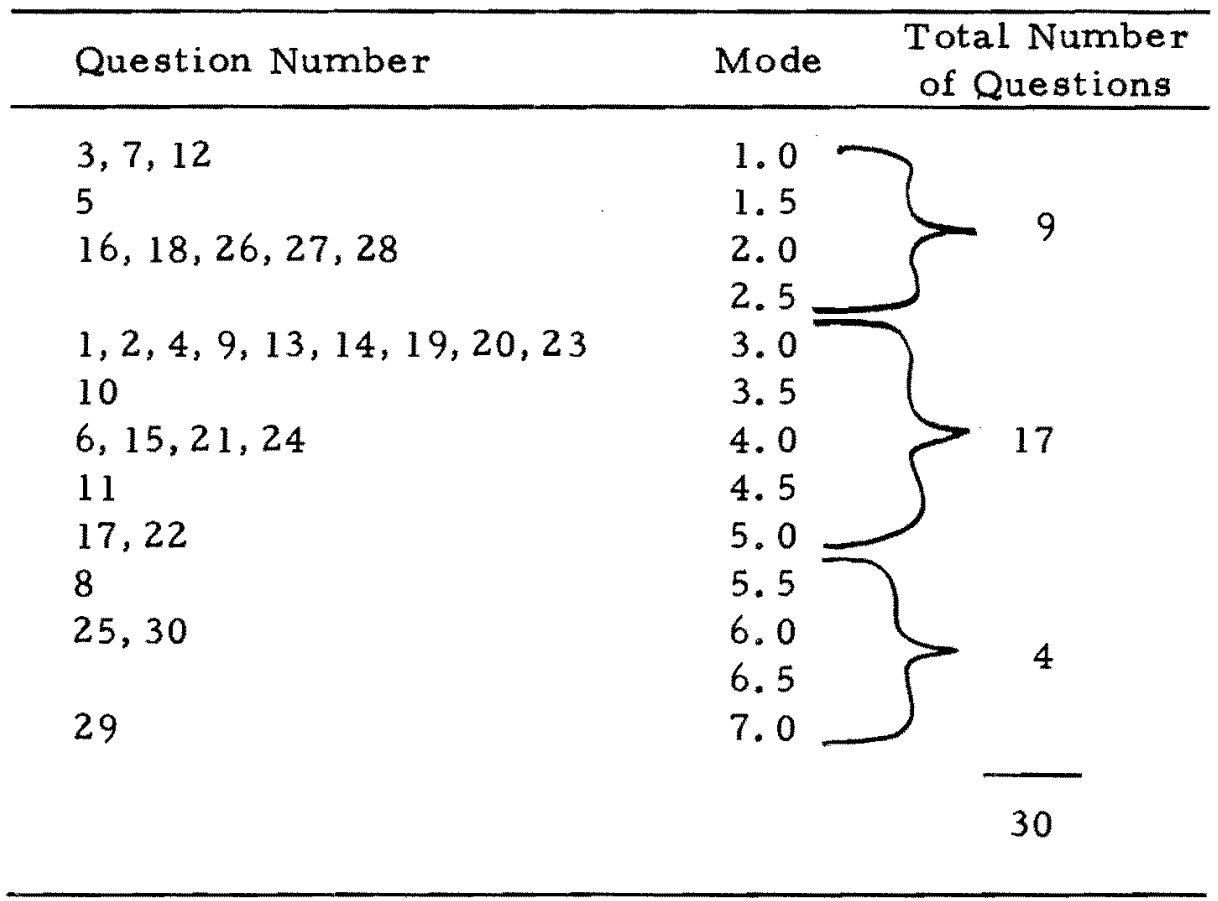

First marriage for both partners was one of the criteria established for our sample population. We felt this was important as a means of eliminating possible unknown variables related to the experience of a previous marriage. A previous marital experience may affect both the individual's emotional maturity and the manner in which a second marriage is approached. We selected people who had been married for not more than four months. This was to account for a time factor to insure that the responses to the questionnaire would be less distorted by events that occurred after marriage. Only one partner of a marriage was selected as a subject. We felt that using 
both marriage partners in a marriage might distort the data because of the following possibilities: they may not complete the questionnaire independently of each other; one partner might complete both questionnaires; or they might compare their completed questionnaires with the possible result being a less honest response for fear of hurting their spouse.

Our final criteria was that the sample populations be limited to those people who filed for marriage licenses in Multnomah County, Oregon.

The sample population consisted of 48 individuals. We subdivided the two basic groups of teenage and adult marriages into the eight categories of marriage shown in Table VIII.

TAB LE VIII

EIGHT CATEGORIES OF MARRIAGES

\begin{tabular}{ll}
\hline \multicolumn{1}{c}{ Respondent } & \multicolumn{1}{c}{ Spouse } \\
\hline 1. Teenage bride & Teenage groom \\
2. Teenage bride & Adult groom \\
3. Adult bride & Teenage groom \\
4. Adult bride & Adult groom \\
5. Teenage groom & Teenage bride \\
6. Teenage groom & Adult bride \\
7. Adult groom & Teenage bride \\
8. Adult groom & Adult bride \\
\hline
\end{tabular}


We selected six individuals for each of the eight categories, giving us a total of 48 individuals.

Through the cooperation of the Multnomah County Clerk's Office, we were allowed to use their files of applicants for marriage licenses. From these records we were able to determine basic information such as age, previous marriage, addresses, and verification that the marriage actually took place.

A table of random numbers was used for the actual selection process with two random numbers being assigned to each category. These numbers were used to select the first marriage in each subsample and then the intervals between marriages. As an example, in category one the random numbers are 3 and 2 . Starting with the most recent marriage on file, we selected the third marriage that fit our criteria, and thereafter selected every second marriage with that same criteria until a total of six individuals had been selected for the category. This process was repeated for each category with a different pair of random numbers being used for each category. The two exceptions to this procedure were category No. 3, adult brideteenage groom, and No. 6, teenage groom-adult bride. In both instances we found so few applications that we took every marriage fitting our criteria. The completed sample population consisted of individuals who were married between September 3, 1970 and October $31,1970$. 


\section{ADMINISTRATION AND COLLECTION OF FINAL QUESTIONNAIRE}

Our design included administering the final questionnaire by mail and asking the respondents to return the questionnaire as soon as possible. Included with the questionnaire was an explanatory cover letter, and pre-addressed, stamped return envelope. We obtained the cooperation of Judge Jean L. Lewis of the Multnomah County Court of Domestic Relations who allowed us to use her letterhead and signature for our cover letter. This letter asked for the respondents' cooperation (see Appendix D). It was our intention to use the court's official sanction of our study as a means of increasing the number of returned questionnaires. In order to supplement the official sanction in our cover letter, we used the Department of Family Services located in room 302 of the Multnomah County Court House as our mailing address.

Although the questionnaires were ready for mailing in midDecember, they were not mailed until January 4, 1971 in order to avoid the confusion of the Christmas holiday. A followup letter was written under the letterhead of the Department of Family Services and signed by Mr. Richard Collins, director of the agency. These letters were mailed three weeks after the initial mailing of the questionnaire (see Appendix F). 
Some questionnaires were returned by the post office because either the addressee was unknown or the individual had moved and left no forwarding address. In these situations, we remailed the questionnaire to the spouse's address, carefully marking each envelope with "please forward."

Two weeks after mailing the follow-up letter we attempted contacting, by telephone, the respondents who had not yet returned their questionnaire. This was our only and final attempt at making direct contact with these respondents. We had limited success as we were unable to obtain phone numbers for all these individuals.

From the initial 48 questionnaires that we sent, 26 questionnaires were completed and returned. The distribution of the completed questionnaires can be seen in Table IX.

TABLE IX

NUMBER OF INITIAL QUESTIONNAIRES RETURNED

\begin{tabular}{cccc}
\hline & Male & Female & Total \\
\hline Teenage & 6 & 9 & 15 \\
Adult & 7 & 4 & 11 \\
Total & 13 & 13 & \\
\hline
\end{tabular}


By inspection, it appears that for women the number of questionnaires which were returned decreased as the age of the woman and her husband increased. No pattern could be observed for men.

Our attempts to contact the remaining 22 people resulted in 12 more replies. Two of these replies came in the form of telephone calls stating that they did not want to complete the questionnaires. Both of the people identified themselves; one was an "adult" woman, who gave no reason for her refusal to cooperate. The other person was an "adult" man. He stated that he refused to complete the questionnaire because of our use of a judge's name on the cover letter. He saw this as an attempt to coerce him into cooperation. In total we received 36 completed questionnaires, two refusals to cooperate, nine people we were unable to contact, and one person who did not return the questionnaire.

The emotional maturity score was computed for each individual respondent. These data were then used in an analysis of our eight categories of marriages which will be discussed in the next chapter. 


\section{CHAPTER IV}

\section{RESULTS}

\section{INTRODUCTION}

This project has attempted to determine if there is a direct relationship between emotional maturity and age at the time of marriage. Comparing teenagers and adults, an emotional maturity scale was used that examined why a person decided to get married and why he chose his particular spouse.

The null hypothesis for this project was: chronological age at the time of marriage is not directly related to emotional maturity. We would expect the emotional maturity scores to be equally distributed among the eight groups.

An analysis of variance of a $2 \times 2 \times 2$ factorial design was conducted, and a $F$ test computed. No effects were statistically significant. That is, neither age of respondent, age of spouse, nor sex, whether taken separately or together in any combination, were related to the degree in which the subjects took things into account in deciding to get married or in choosing their spouse. The same results were obtained by a multiple-regression analysis using age as a continuous variable. Thus, the results of the project were essentially negative; age at marriage was not found to be directly related to emotional maturity. 
In interpreting these results, several things need to be taken into consideration. One is the poor agreement among the judges regarding the maturity value of the items. A second is the failure of the items to discriminate the respondents'reported consideration of the items in their decision to marry and their choice of spouse. A third is the possibility of the conclusion being correct that age has no bearing on such marital decisions even when age of spouse or sex is controlled for.

It was found that the subjects did report taking into consideration in their marital decisions those matters that the experts rated as mature things to consider. An examination of the context of these items found that subjects did not give consideration to why they should get married, but only to why they should marry their particular spouse.

Returning now to each of these points in detail, we shall look first at the data obtained from the expert judges and then at the data obtained from the subjects.

\section{DATA FROM THE EXPERTS}

We found that there was a wide spread of responses among the experts on each item on their questionnaire. On a seven point scale, we found that 58 of the 67 items (before the aberrant responses were discarded) were rated differently by the expert judges by a difference 
of three points or more. In the following figure, the shaded area represents agreement, that is, either perfect agreement or up to a difference of two points on the seven-point scale. Despite this tolerant definition of agreement, only nine items found the judges in ag reement.

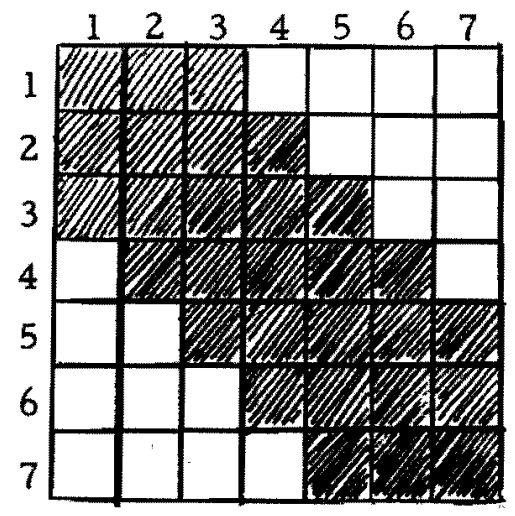

Agreement 9 Disagreement 58

67 items

Figure 1. Acceptance criteria for modal responses.

We found that there was more agreement among the experts on those items relating to the choice of spouse than on those items relating to the decision to get married. Examining each expert's response to each item, we find the following number of aberrant responses by each expert (Table X). We are defining an aberrant response as a response which was at least one number apart from any other response. From Table $X$ it can be seen that four people had a high number of aberrant responses--experts No. 4, 6, 8, and 10 (see Appendix B). There was also a difference in response according to sex. All of the women had aberrant responses while only one-half of 
TABLE X

NUMBER OF ABERRANT RESPONSES BY EXPERTS

\begin{tabular}{lllllllllllllll}
\hline & \multicolumn{11}{c}{ Expert Number } \\
\cline { 2 - 11 } & 1 & 2 & 3 & 4 & 5 & 6 & 7 & 8 & 9 & 10 & 11 & 12 \\
\hline $\begin{array}{l}\text { Sex of } \\
\text { expert }\end{array}$ & $M$ & $M$ & $M$ & $M$ & $M$ & $F$ & $F$ & $M$ & $M$ & $F$ & $M$ & $F$ \\
$\begin{array}{l}\text { Number of } \\
\text { abexrant } \\
\text { responses }\end{array}$ & 0 & 1 & 0 & 8 & 0 & 11 & 2 & 6 & 3 & 7 & 0 & 3 \\
\hline
\end{tabular}

the men had aberrant responses. Even though the women varied from the mode more than the men, they did not vary on the same items, i. e., on any one item there was a good chance of one woman varying, but little chance of more than one woman varying.

\section{DATA FROM THE SUBJECTS}

From the item analysis it was found that the items failed to discriminate. They failed to discriminate in that all but seven of the 30 items were answered almost identically by our 36 subjects (see Appendix I). On 19 of the 23 items with almost total agreement, the subjects reported "did not consider." The subjects reported "strongly considered" on only four items, and these items all dealt with the subject's choice of spouse. These were items No. 19, "I married my spouse because I respected and/or trusted him or her," No, 21, "I married my spouse becauge we loved each other," No. 25 , 
"I married my spouse because we enjoyed each other and got along well," and No. 29, "I married my spouse because we could communicate with each other."

Inspection of the remaining seven items showed that any difference was insignificant. Of these seven items (Nos. 1, 8, 11, 17, 22, 24, and 30; Appendix E), four items were reported "strongly considered" by the subjects. Three of these four items, No. 17, "I married my spouse because we could depend on each other, "No. 22 , "I married my spouse because we wanted to live together in a similar way," and No. 30, "I married my spouse because he or she made me feel secure," all were concerned with the subject's choice of spouse. Item No. 1, "I got married to have a home and family," was concerned with the decision to get married. This was the only item of the 14 items in this part of the questionnaire that the subjects reported "strongly considered." The other 13 items the subjects reported "did not consider" in their decision to get married.

In comparing the subjects to the experts, we found that the subjects reported taking into consideration in their choice of spouse those is sues that the experts considered as showing maturity. The subjects did not take into consideration those items that the experts considered immature. This can be seen in Tables XI and XII. It should be remembered that the judgments of the experts and of the subjects were made completely independently of each other. 
TABLE XI

CORRESPONDENCE BETWEEN SUBJECTS'

AND EXPERTS' RESPONSES

\begin{tabular}{lcc}
\hline $\begin{array}{c}\text { Subjects' Judgment } \\
\text { of Item }\end{array}$ & \multicolumn{2}{c}{$\begin{array}{c}\text { Experts' Judgment } \\
\text { of Item }\end{array}$} \\
\cline { 2 - 3 } & Mature & Immature \\
\hline Did consider & 7 & 1 \\
Did not consider & 1 & 21 \\
\hline Yule's $Q=.98 ; p<.01$ &
\end{tabular}

The basis for this correlation is shown more completely in Table XII. This table gives the responses of the subjects and the experts on the 30 items. The experts' responses of 5, 6, or 7 give a high maturity value to the item, and the experts' responses of 1-4 judged the item "immature." The table indicates that the subjects did consider seven out of the eight items which the experts regarded as mature and did not consider 21 out of the 22 items which the experts regarded as immature.

From Tables XI and XII it can be seen that there were two items out of the 30 items that the subjects differed on. These were items No. 8 and No. 21 . Item No. 8 , "I got married to experience a fuller sex life, "was the item with the greatest discrepancy between the subjects and the experts. The experts saw this as a mature reas on to get married while the majority of the subjects reported not 
TABLE XII

EXPERTS' AND SUBJECTS' MODAL RESPONSES TO THE QUESTIONNAIRE

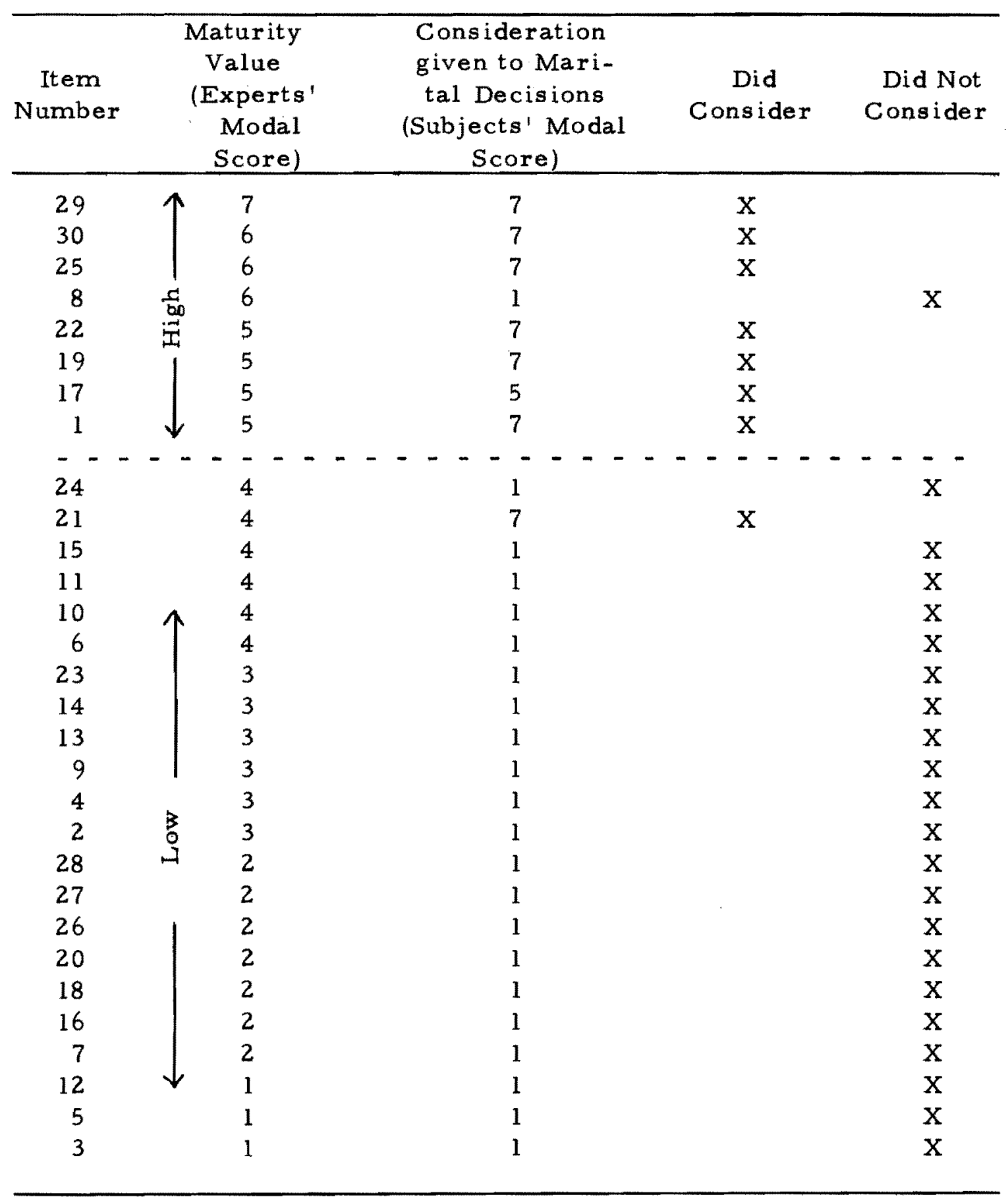


taking this into consideration in their decision to marry. Item No. $21_{5}$ "I married my spouse because we loved each other," was considered to be important by the subjects in their choice of spouse, while the experts gave this a rating of "4," indicating that this was neither mature nor immature.

The subjects reported "strongly considered" to only one of the 14 items pertaining to why they decided to marry, while they reported "strongly considered" to one-half of the items pertaining to the choice of spouse. Thus, it seems that the subjects only gave consideration to why they should marry their particular spouse and not to why they should get married.

Possible reasons for this and for the rest of our findings will be discussed in the next chapter. 


\section{CHAPTER V}

\section{DISCUSSION OF RESULTS}

\section{LIMITATIONS}

A problem existed in operationalizing the concept of emotional maturity. We were unable to distinguish whether the experts had a problem in differentiating degrees of emotional maturity, or if it was a problem in our concept. It is possible that emotional maturity is not translatable into operationally qualitative terms. In our use of the seven point scale, we allowed the experts to choose a middle point, without forcing them to differentiate. Consequently, they avoided making a distinction between mature and immature items.

There were several limitations in the methodology of our study. The questionnaire construction was limited due to the following:

1) The questionnaire was not sufficiently validated.

2) It was difficult for the experts to respond to statements 1 through 32 on the experts' questionnaire, since these items were inconsistent in that it was necessary for the experts to continually change their frame of reference in responding to the items. For example, question No. 1 reads, "People marry in order to live together with societal approval, "and 
question No. 2 reads, "Marriage provides a way out of an unpleasant school experience." They were also inconsistent in that they differed from the subjects' questionnaire. The second set of questions were all phrased in the same manner, i. e., "I married my spouse because. . .," and they all referred to an individual rather than the general population.

3) On the final questionnaire, the phrasing of the set of items regarding motivations for marrying was changed so that all items referred specifically to the individual respondent. For example, item No. 3, "Individuals marry to experience a fuller sex life," was changed to item No. 8 on the respondents' questionnaire which read, "I got married so that I could experience a fuller sex life."

The method of sampling was limited due to the small size of the sample and the fact that some observations were missing (more teenagers than adults returned the questionnaires).

The literature shows that men and women have different priorities in what they regard as important in making the decision to marry and in selecting a spouse. In our study, there were twice as many male experts as female experts. Thus, the men decided what was mature and immature. Consequently, this would limit any findings we would have in regard to women. 
Our study was further biased because the 12 panel members all represented the profession of social work with the exception of one member who also had a Ph. D. in psychology. Thus, we have a "social workers' measure" of emotional maturity.

The following are additional independent variables that we did not take into account:

1) We failed to consider whether people of different backgrounds marry and select a spouse for different reasons.

2) We did not ask for race or religion when collecting identifying information from the subjects.

3) Our questionnaire may have a "WASP" orientation. Ten of the 12 experts were white, Anglo-Saxon, Protestants. The other two were from different ethnic and religious backgrounds. These two experts had the largest number of aberrant responses. Thus, we end up with a "WASP" measure of what are mature or immature reasons to get married or select a spouse.

\section{IMPLICATIONS}

There are two primary conclusions which can be drawn from this study. The first pertains to the concept of emotional maturity, and the second pertains to the reasons why people marry. 
First, our use of the concept of emotional maturity caused difficulty. The concept of emotional maturity is not operational as there are no objective criteria anchoring the concept with upper and lower limits against which emotional maturity can be measured. The term is so vague that each expert was, in a sense, measuring from his frame of reference without agreed upon parameters. Several of the experts felt that we should have asked each of them for their definition of emotional maturity. For example, expert No. 5 said

It would seem that one's response to this questionnaire depends greatly upon the definition of maturity. This might well be highly variable between respondents. I would have been more comfortable stating my definition of maturity first and then selecting ratings consistent with that frame of reference. As it stands now, you might or might not be able to infer what my definition of maturity is through an analysis of the responses.

In reviewing other comments by the experts, we found that each expert offered his definition of maturity, and these definitions all differed from one another.

Our data also showed a wide disagreement among the experts. What one expert rated as mature, another expert rated as immature.

Pearson, in his doctoral dissertation, states

... the term 'emotional immaturity' is used so narrowly as to be restricted to descriptions of behavior seen in temper tantrums by some writers and so broadly as to be synonymous with emotional maladjustment by others, with many gradations between. No one appears to have taken cognizance of this situation or to have made any effort to secure a uniform definition and usage. 1

${ }^{1}$ John Sumner Pearson, Ph. D., "Psychometric Correlates 
Thus, we would conclude that people should cease using the term

"emotional maturity" since it is used to subsume such widely different kinds of behavior.

Our second conclusion pertains to the set of items regarding motivations to marry. The experts tended to rate these items as immature and the subjects did not give consideration to these items. The majority of the subjects chose "did not consider" in 13 out of 14 items in this section of their questionnaire.

One possible reason for this is that these items seem to be concerned with motivations of which an individual would not normally be aware. These items dealt with psychological, unconscious motivations. The subjects could not be expected to admit to these motivations even if they were in fact related to their decision to get married.

Another possible reason for the subjects rating these items "not considered" and for the experts rating them as immature, was that the items seemed to have a negative connotation. Historically, psychology has emphasized the weaknesses rather than the strengths of people. The literature also gives numerous negative reasons why people marry but gives few, if any, positive reasons. In this study, we also used negative motivations as reasons to get married. One of the experts after completing this section of the questionnaire felt that

of Emotional Immaturity," A Guide to Dissertations and Monographs Available in Microfilm, XV (Ann Arbor, Michigan: University Microfilm, 1955), p. 2129. 
"marriage was a bad thing and that it could be expected to produce nothing but trouble" (expert No. 7).

A third possible reason for this was that initially we believed that getting married involved some sort of rational decision-making process. However, we now see that we failed to get at the real reasons why people get married. Though the items used as motivations for marriage were found throughout the literature and were found in studies done in the past, they do not appear to be the "real" reasons why people get married. The problem seems to be that we were asking psychological reasons, when actually marriage is a sociological phenomena. It is assumed by most people from early childhood that they will one day marry. They seldom consider the alternative of not marrying. Marriage is a learned, cultural phenomena which most people never question. In this society, it is the only sanctioned way of getting love. Therefore marriage is a necessity.

\section{RECOMMENDATIONS FOR FURTHER STUDY}

We feel that the notion of emotional maturity should be discarded; however, the concept of mate selection is a valid one. It would be possible to compare teenagers to adults, and males to females in terms of the criteria they used in the selection of their 
spouse. This would be one way of looking at any differences there might be between "teenage marriages" and "adult marriages." 


\section{SELECTED BIBLIOGRAPHY}

Avery, Curtis. "Toward Understanding the Problems of Early Marriage, "Family Life Coordinator, IX, Autumn (1960), p. $27-34$.

Bolton, Charles D. "Mate Selection as the Development of a Relationship, " Marriage and Family Living, XXIII (August 1969) p. $234-240$.

Burchinal, Lee. "Research on Young Marriage: Implications for Family Life Education," Family Life Coordinator, IX, Autumn (1960), p. 6-24.

Burchinal, Lee. "School Policies and School Age Marriage," Family Life Coordinator, VIII (March 1960), p. 43-48.

Burchinal, Lee. "Trends and Prospects for Young Marriages in the U.S., " Journal of Marriage and the Family, XXVII (May 1965), p. $243-254$.

Coombs, Robert. "A Value Theory of Mate Selection," Family Life Coor dinator, X (July 1961), p. 51-53.

Dean, Dwight G. "Romanticism and Emotional Maturity: A Further Exploration, "Social Forces, XLIV (March 1964), p. 298-303.

Duvall, Evelyn. "Adolescent Love as a Reflection of Teen-Ager's Search for Identity, "Marriage and Family Living, XXVI (May 1964), p. $180-190$.

Duvall, Evelyn. "Student Marriages," Marriage and Family Living, XXII (February 1960), p. 76-77.

Duvall, Evelyn and Reuben Hill. When You Marry. New York, 1948.

Farber, Seymour and Roger Wilson (ed.). Teenage Marriage and Divorce. Berkeley, California, 1967. 
Glick, Paul C. and Robert Parke, Jr. "Prospective Changes in Marriage and the Family, "Journal of Marriage and the Family, XXIX (May 1967), p. 249-256.

Heath, Douglas H. Explorations of Maturity. New York, 1965.

Kirkendall, Lester. Too Young to Marry? Washington, D. C., 1957. (Public Affairs Pamphlet No. 236)

Landis, Judson T. and Mary G. Landis. Building a Successful Marriage. New York, 1970.

Landis, Paul H. Making the Most of Marriage. New York, 1970.

Lantz, Herman R. and Eloise Snyder. An Examination of the ManWoman Relationship. New York, 1969.

Martinson, Floyd. "Ego Deficiency as a Factor in Marriage - - A Male Sample, "Marriage and Family Living, XXI (February 1959), p. $48-52$.

Monahan, Thomas P. "Does Age at Marriage Matter in Divorce ?" Social Forces, XXXII (October 1953), p. 81-87.

Nash, John. Developmental Psychology: A Psycholobiological Approach. New Jersey, 1970.

Pearson, John Sumner. "Psychometric Correlates of Emotional Immaturity," A Guide to Dissertations and Monographs Available in Microfilm, XV (Ann Arbor, Michigan: University Microfilm, 1955), p. 2129.

Pressey, Sydney and Raymond Kuhlen. Psychological Development Through the Life Span. New York, 1957.

Prince, Alfred. "Factors in Mate Selection," Family Life Coordinator, X (July 1961), p. 55-58.

Smith, Eleanor and J. H. Greenberg Monane. "Courtship Values in a Youth Sample, "American Sociological Review, XVIII (December 1953), p. 635-640.

Statistical Abstract of the United States: 1970. Washington, D. C. , 1970. (Report of the U.S. Bureau of the Census) 
Strauss, Anselm. A Study of Three Psychological Factors Affecting Choice of Mate. Ph. D. Thesis, University of Chicago, 1945.

Winch, Robert F. and Louis Wolf Goodman (ed.). Studies in Marriage and the Family. New York, 1968. 


\section{APPENDIX A}

\section{EXPERTS' QUESTIONNAIRE}

This questionnaire is part of a Master's thesis. Our interest in this thesis grew out of our experience while working with you at the Family Services Department. We became interested in how the age of a person, at the time they maried, effected their marriage. One of us then became interested in why people marry, another in why they choose their particular spouse, and another in the relationship between the age and the emotional maturity of an individual. We decided to combine our interests into a Master's thesis. In this thesis we are attempting to evaluate the interrelationships between age and emotional maturity, the reason a person gets married, and the reason a person chooses his particular spouse.

We know that you are frequently asked to complete questionnaires, and consequently we appreciate the time that you are giving us. As experts in the field of marital counseling you come in contact with a wide variety of people whose motivations for getting married differ greatly. After our reading the literature and working at the Family Services Department, we have compiled a list of reasons why people marry. These reasons are listed below. We would like you to rate each reason according to how emotionally mature you feel the response is. You might think in terms of "How emotionally mature is the individual who is motivated to marry primarily due to " then fill in with the concept outlined in the individual statements below). Please rate each statement on a scale from 1 to $7-1$ is totally immature and 7 is very mature. Please circle one mark on the line next to each statement.

1. People marry in order to live together with societal approval.

2. Marriage provides a way out of an unpleasant school experience.

3. Individuals marry so that they can experience a fuller sex life.

4. Marriage is used to acquire higher economic status.

5. Men marry in order to become fathers.

6. Individuals marry to obtain companionship.

7. Marriage is used to legalize common-law relationships.

8. People marry because in our society family patterns encourage children to marry and start their own families.

9. Men marry to avoid the draft.

10. People marry because they are in love.

11. Marriage is used as a means to end the social stigma of being a single adult.

12. People marry to satisfy their need to be cared for.

13. Girls marry in order to become mothers.

14. People marry because they want help with the workload imvolved in day to day living.
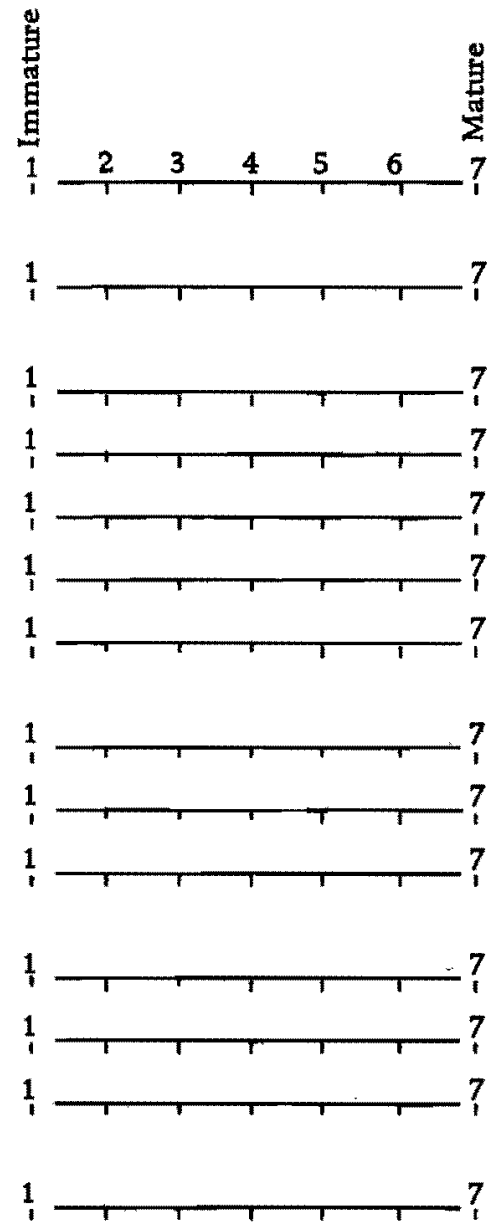
15. Individuals marry to have a home and family.

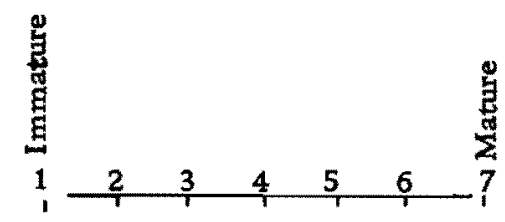

16. People marry "on the rebound" following the breakup of an intimate relationship.

17. Marriage is a means of ending the boredom of dating and courtship.

18. Individuals marry to enbance their masculine or feminine identity.

19. People get married due to parental pressure.

20. Marriage is used to acquire higher social status.

21. People many to escape from an unpleasant work situation.

22. Individuals marry as a matter of convenience.

23. People marry in pursuit of personal happiness.

24. Individuals marry to enhance their public image.

25. People many as a way of assuring themselves they are desirable.

26. Individuals marry to become aduits with privileges.

27. People marry because their friends are getting married and it is the thing to do.

28. Premarital pregnancy motivates couples to marry.

29. People marry to escape from an unhappy home situation.

30. Individuals marry to avoid loneliness.

31. Men marry to present a family image as a means of gaining promotions at work.

32. People manty to become parents.
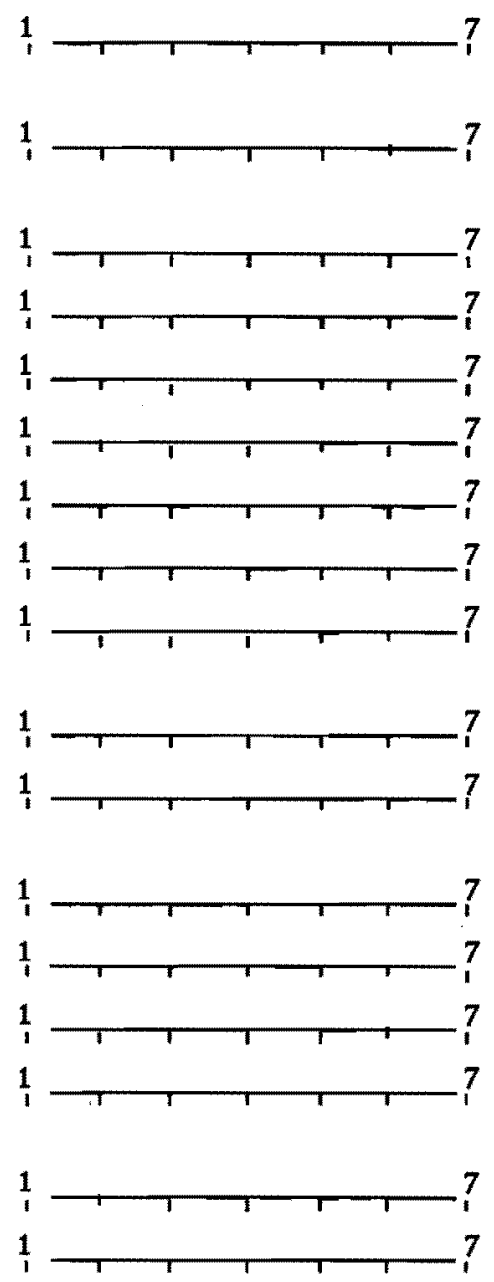

The following is a list of reasons why people chose their specific mate. Please rate each statement according to how emotionally mature you feel the response is. You might think in terms of "How emotionally mature is the individual who married his spouse primarily because " then fill in with the concept outlined in the individual statements listed below. Please circle one slash mark for each item. Thank you.

I married my spouse because:

33. he reminded me of a member of my family.

34. we were going to have a baby.

35. our families were part of the same social class.

36. he was a member of the same race.

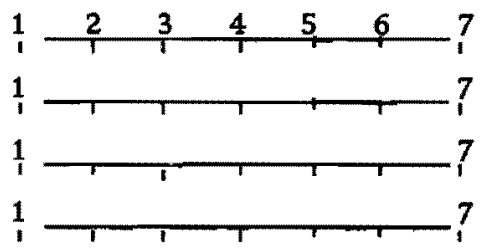


I married my spouse because:

37. we could depend on each other.

38. he always looked neat and well-groomed.

39. we lived in the same neighborhood.

40. he accepted my family's guidance.

41. he made me feel important.

42. she was a good cook, could sew and kept a neat and clean house.

43. we loved each other.

44. our families had similar values and traditions.

45. his occupation appealed to me.

46. we both wanted to have children.

47. he needed me.

48. we enjoyed each other and got along well.

49. he was the same religion as I.

50. I respected him.

51. he was the first person who I was intimate with.

52. we attended the same school.

53. he was mature.

54. we agreed on the way we would raise children.

55. he gave me a feeling of belonging.

56. we can communicate.

57. he was one of the few people available for me to marry.

58. I trusted him.

59. he was ambitious and wanted to get ahead.

60. he understood me.

61. I can tell him what to do.

62. I felt that I should marry someone with the same political interests.

63. he made me feel secure.

64. we wanted to live in a similar way.

65. he tells me what to do.

66. we agreed on when we would have children.

67. he knew "this way around."
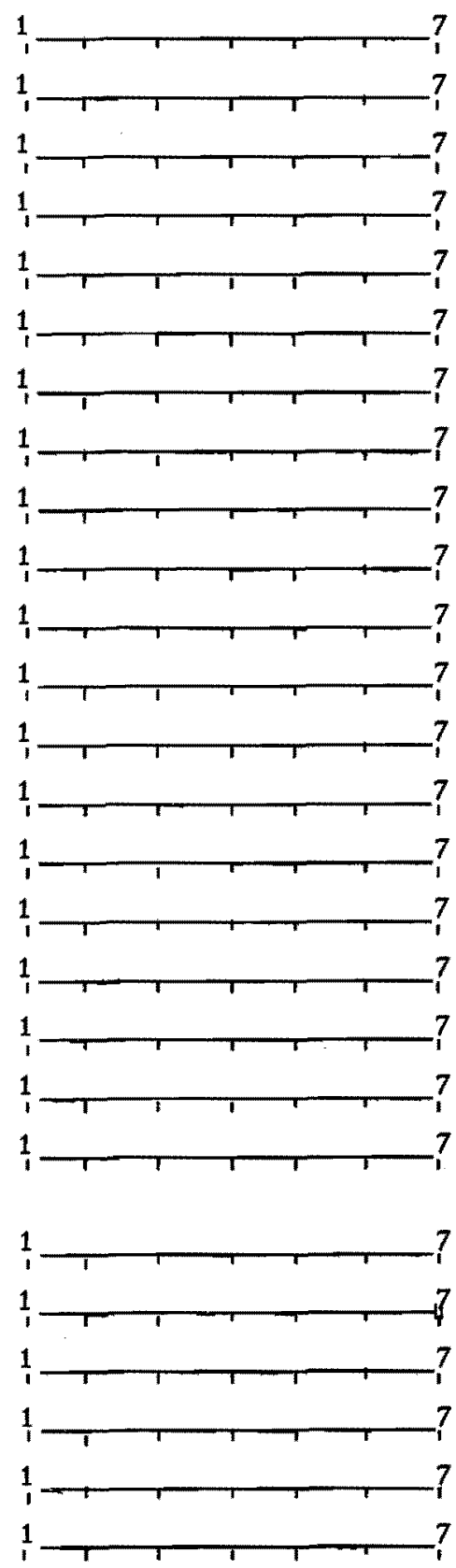
Thanks so much for your time. We would really appreciate your attention for a few more minutes. In the space provided below, could you please note any problems you encountered while completing this questionnaire, i.e., lack of clarity. Any additional comments you'd like to make would be appreciated. Upon completion of this research we will let you know the results. Thanks again. - Pat Duclos, Dave Thomas, Joanne Zusman. 


\section{A PPENDIX B}

IDENTIFYING CHARACTERISTICS OF PANEL OF EXPERTS

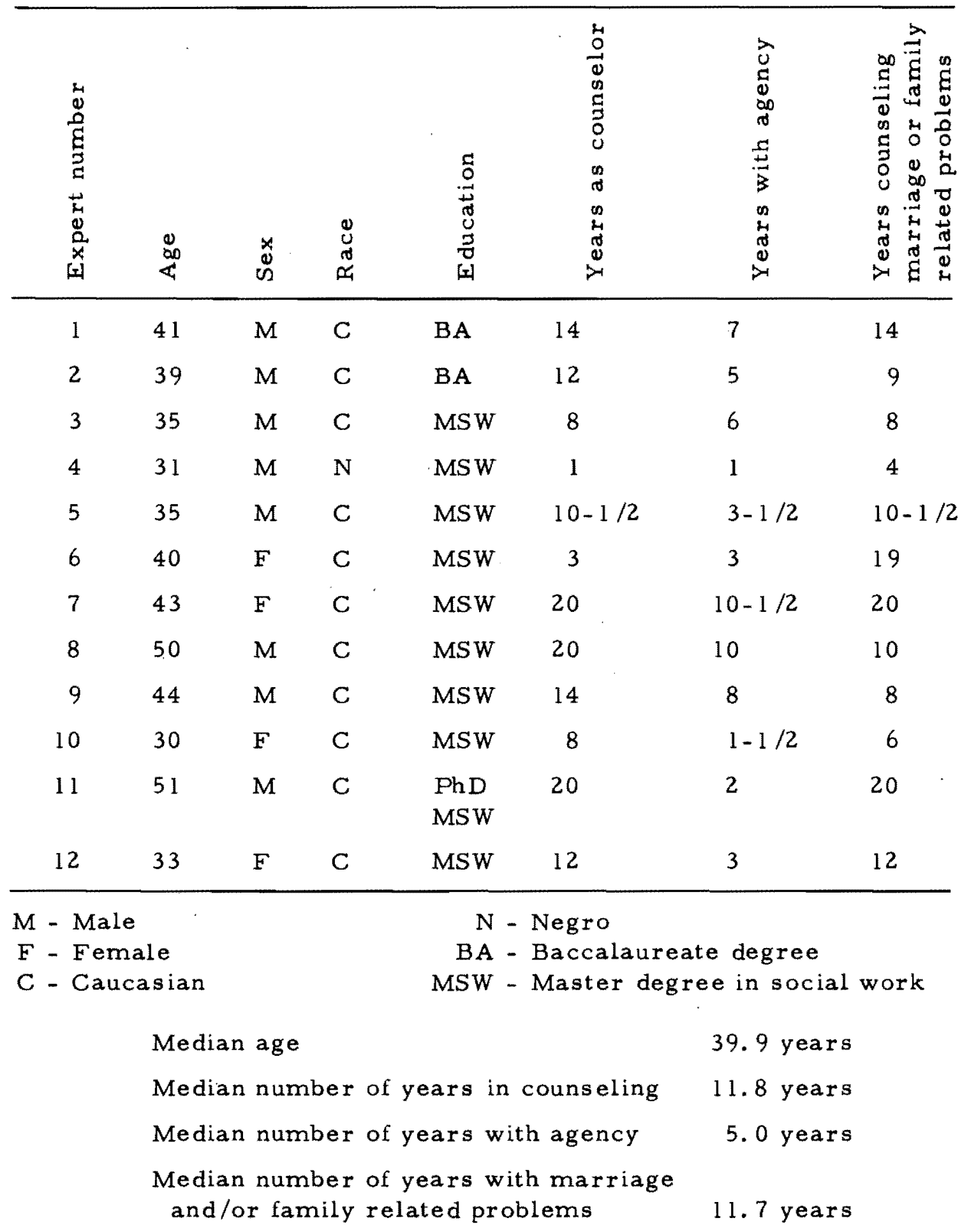




\section{APPENDIX C \\ RATIONALE FOR SEIECTION PROCEDURE USED IN CONVERTING PANEL OF EXPERTS' QUESTIONNAIRE TO RESPONDENTS' QUESTIONNAIRE}

The 67 statements rated by the panel of experts were reduced to 30 and then converted to questions on the respondents' questionnaire. We considered both the range and the mode in making this conversion in order to use questions reflecting high agreement among the experts as well as all levels of emotional maturity. All statements with a range of 1 and 2 were used with the exception of the following eight that were found to be inadequate.

\begin{tabular}{|c|c|}
\hline $\begin{array}{l}\text { Statement } \\
\text { number }\end{array}$ & Statement \\
\hline 7 & $\begin{array}{l}\text { Marriage is used to legalize } \\
\text { commonlaw relationships }\end{array}$ \\
\hline 8 & $\begin{array}{l}\text { People marry because in our } \\
\text { society family patterns encourage } \\
\text { children to marry and start their } \\
\text { own families }\end{array}$ \\
\hline 10 & $\begin{array}{l}\text { People marry because they are } \\
\text { in love }\end{array}$ \\
\hline 22 & $\begin{array}{l}\text { Individuals marry as a matter of } \\
\text { convenience }\end{array}$ \\
\hline
\end{tabular}

24 Individuals marry to enhance their public image
People marry as a way of assuring themselves they are desirable

I married my spouse because she was a good cook, could sew, and keep a neat and clean house

I married my spouse because we both wanted to have children

\section{Explanation}

could be either mature or immature depending on motivation

the link between practices necessary for the survival of the group and those which emerge as traits of individuals is hard to identify

the concept of love is so overworked today that it has widely different meanings to different people

this statement could be subject to a wide interpretation and may be a reflection of pathological behavior which is not the intention of this study

there may be an inconsistent interpretation of public image, and the statement was similar to statements \#4, "Marriage is used to acquire higher economic status," and \#20, "Marriage is used to acquire higher social status"

eliminated because people who feel strongly that they are not desirable, may be reflecting pathological behavior

this question related only to women--we could not develop or expand the statement so as to be bisexual

eliminated because it was similar to statement \#5, "Men marry in order to become fathers," and \#13, "Girls marry in order to become mothers" 
The following statements with a range of 1 and 2 were combined:

\begin{tabular}{|c|c|}
\hline $\begin{array}{l}\text { Statement } \\
\text { number }\end{array}$ & Statement \\
\hline 2 & $\begin{array}{l}\text { Marriage provides a way } \\
\text { out of an unpleasant school } \\
\text { experience }\end{array}$ \\
\hline 21 & $\begin{array}{l}\text { People marry to escape from } \\
\text { an unpleasant work situation }\end{array}$ \\
\hline 29 & $\begin{array}{l}\text { People marry to escape from } \\
\text { an unhappy home situation }\end{array}$ \\
\hline 5 & $\begin{array}{l}\text { Men marry in order to become } \\
\text { fathers }\end{array}$ \\
\hline 13 & $\begin{array}{l}\text { Girls marry in order to become } \\
\text { mothers }\end{array}$ \\
\hline
\end{tabular}

Explanation

these three statements became question \#7 on the respondents' questionnaire: "I got married to get out of an unpleasant school experience or an unpleasant work situation, or an unhappy home situation." They were combined because they all related to the use of marriage as an escape from an unpleasant situation.

both statements relate to parenthood as an objective of marriage and were combined into question \#11 on the respondents" questionnaire, "I got married to become a parent."

The following eight statements with a range of 3 were used in the respondents questionnaire.

56

63
I married my spouse because we can communicate

I married my spouse because he made me feel secure

Individuals marry to have a home and a family

Marriage is used as a means to end the social stigma of being a single adult

I married my spouse because he reminded me of a member of my family

I married my spouse because we were going to have a baby

I married my spouse because I respected him

I married my spouse because I trusted him this statement was used because of its high modal value of 7

this statement was used because of its high modal value of 6 . Both statements were considered high, mature by the experts

this statement was selected because it relates to the traditional expectation associated with marriage in our society

this statement was chosen because it relates to the social expectation that something is peculiar about the individual who does not marry

this statement was selected because it related to the family as an influencing factor in mate selection

this statement was selected because it relates to premarital sex as a motivating factor in mate selection

these two statements were selected because they relate to respect and trust which are two essential elements in a marriage relationship. Both statements were combined into question \#19 on the respondents' questionnaire: "I married my spouse because I respected and/or trusted him or her." 
The following statement with a range of 4 was used.

\section{Statement}

number Individuals marry so that they can experience a fuller sex life
3

\section{Statement}

\section{Explanation}

this statement was selected because it specifically related sex as a motivating factor in the decision to marry

The completed respondents' questionnaire consisted of 30 questions, 22 of which had a range of 1 and 2 , 7 had a range of 3 , and 1 had a range of 4 . 
APPENDIX D

LETTER ENCLOSED WITH SUBJECTS' QUESTIONNAIRE

\author{
Circuit Court of Oregon \\ Fourth Judicial District - Dept. No. 12 \\ County Courthouse \\ Portland, Oregon 97204
}

Jean L. Lewis

Judge

December 1, 1970

Dear

I am asking you to spend a few moments of your time to complete the enclosed questionnaire. Your cooperation is needed in a research study of newly married persons. This study concerns the effect of age on the decision to marry. The study is being done by a group of graduate students at Portland State University School of Social Work. Your name was selected in a random sample from the list of applicants for marriage licenses in the Multnomah County Clerk's Office. Your name will not be used in the report.

I appreciate your time and effort in completing this questionnaire. When you have finished, please return it in the enclosed, self-addressed, stamped envelope as soon as possible. If you have any questions or comments regarding this questionnaire, please contact Mr. Donald Welch at 227-8411, extension 281 .

$$
\text { Yours truly, }
$$

JEAN L. LEWIS Judge 


\section{APPENDIX E}

\section{SUBJECTS' QUESTIONNAIRE}

\section{Instructions:}

We ask you to please complete this questionnaire without the assistance of your spouse. There are 30 statements on the questionnaire. Items 1 through 14 have to do with possible reasons why you decided to marry. Items 15 through 30 have to do with possible reasons why you chose your mate. You are asked to answer the items on the questionnaire simply by circling a number on the scale beside each statement.

As you read each item, circle the number on the scale which corresponds with the amount of consideration you gave that item when you made your decision to marry. Below is a sample item:

"I married my spouse because he was a member of the same church as myself."

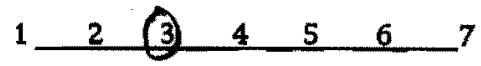

If being a member of the same church was of no importance to you in choosing your marsiage partner then you would circle number 1 on the rating scale. If you gave it some consideration you would circle one of the higher numbers. If this was extremely important to you in choosing your marriage partner then you would circle number 7 . Circle any number on the scale from 1 to 7 according to the item's importance to you.

Before beginning the questionnaire, please complete the following identifying information. Thank you.

Your sex Your age Date of marriage Spouse's age

Please circle one number (slash mark) on the line next to each statement. 1 = a factor you did not consider in your decision to get married. $7=\mathrm{a}$ factor you strongly considered in your decision to get married.

1. I got married to have a home and family.

2. I got married because I wanted help with the workload involved in day to day living.

3. I got married to avoid the draft or to help my husband avoid the draft.

4. I got married to acquire a higher social status.

5. I got married because my parents wanted me to.

6. I got married in order to live together with someone of the opposite sex with society's approval.

7. I got married to get out of an unpleasant school experience, or an unpleasant work situation, or an unhappy home situation.
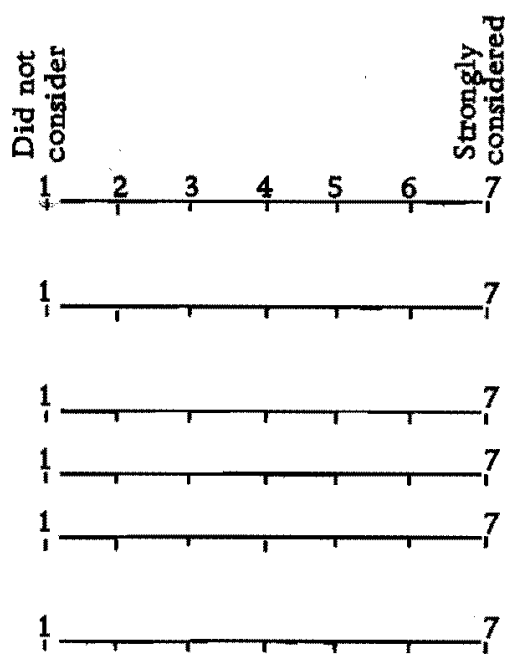

1

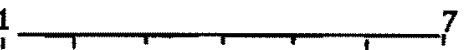


8. I got married so that I could experience a fuller sex life.

9. I got married to end the boredom of dating and courtship.

10. I got married to acquire a higher economic status.

11. I got married to become a parent.

12. I got married "on the rebound" following the breakup of an intimate relationship.

13. I got married to avoid loneliness.

14. I got married to end the social stigma of being a single adult.
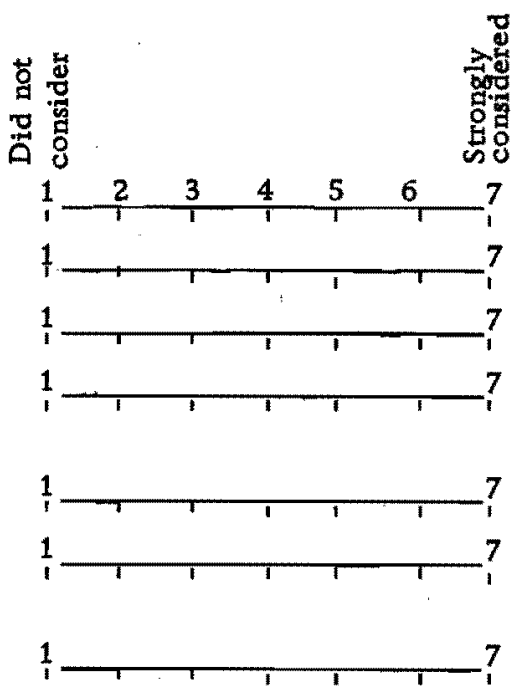

Please circle one number (slash mark) on the line next to each statement.

$1=$ a factor you did not consider in your choice of spouse.

7 a a factor you strongly considered in your choice of spouse.

15. I married my spouse because our families had similar values and traditions.

16. I married my spouse because I could tell him or her what to do.

17. I married my spouse because we could depend on each other.

1

1

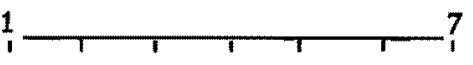

1
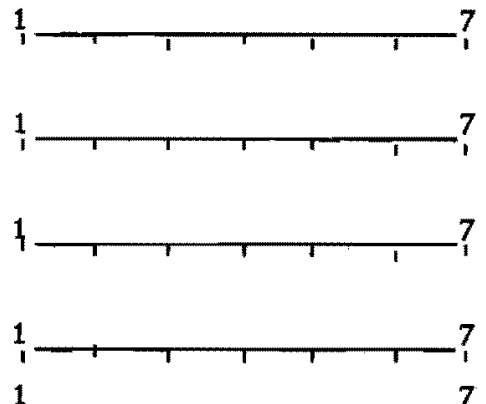

1
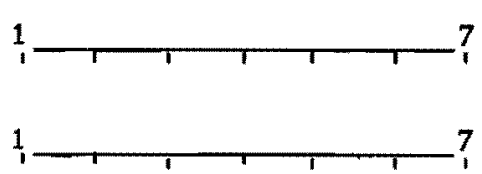

1

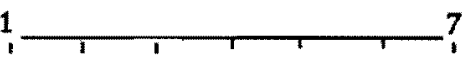

1
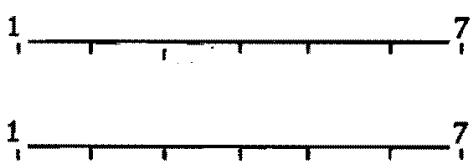

26. I married my spouse because he or she accepted my family's guidance. 
27. I married my spouse because he or she was one of the few people available for me to marry.

28. I married my spouse because he or she could tell me what to do.

29. I married my spouse because we could communicate with each other.

30. I married my spouse because he or she made me feel secure.

Comments would be appreciated. Thank you.
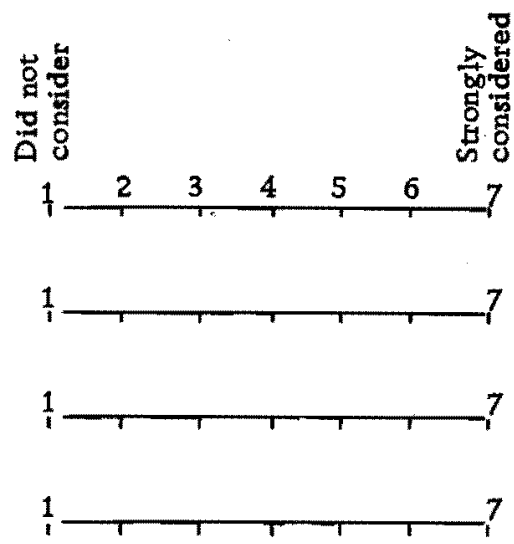


\title{
APPENDIX F \\ FOLLOW UP LETTER TO SUBJECTS
}

\author{
Circuit Court of Oregon \\ Department of Domestic Relations \\ Multnomah County Courthouse \\ Portland, Oregon 97204 \\ Department of Family Services \\ January 26, 1971
}

Dear

I am writing in regard to the questionnaire which you recently received in the mail. Judge Jean L. Lewis of the Circuit Court has asked for your cooperation in this study. As only forty-eight questionnaires have been sent out, it is necessary that every questionnaire be completed and returned.

If you have misplaced the questionnaire or have any questions, please call Mr. Donald Welch at 227-8411, extension 281. We would appreciate a response from you as soon as possible.

Thank you for your cooperation.

Very truly yours,

RICHAR D E. COLLINS, MSW

Director

Department of Family Services 
APPENDDX G

EXPERTS' RESPONSES TO QUESTIONNAIRE

\begin{tabular}{|c|c|c|c|c|c|c|c|c|c|c|c|c|}
\hline \multirow{2}{*}{$\begin{array}{c}\text { Item } \\
\text { number }\end{array}$} & \multicolumn{12}{|c|}{ Expert number } \\
\hline & 1 & 2 & 3 & 4 & 5 & 6 & 7 & 8 & 9 & 10 & 11 & 12 \\
\hline 1 & 3 & 5 & 4 & 6 & 4 & 4 & 5 & 5 & 3 & 4 & 4 & 3 \\
\hline 2 & 2 & 2 & 2 & 2 & 2 & 1 & 1 & 1 & 1 & 1 & 2 & 1 \\
\hline 3 & 3 & 6 & 6 & 5 & 5 & 4 & 7 & 6 & 5 & 2 & 3 & 2 \\
\hline 4 & 3 & 5 & 4 & 4 & 3 & 1 & 4 & 4 & 3 & 4 & 3 & 3 \\
\hline 5 & 4 & 5 & 4 & 3 & 5 & 3 & 5 & 4 & 5 & 7 & 3 & 2 \\
\hline 6 & 4 & 5 & 6 & 2 & 5 & 5 & 5 & 6 & 7 & 7 & 5 & 4 \\
\hline 7 & 2 & 5 & 4 & 2 & 2 & 4 & 4 & 4 & 3 & 1 & 3 & 2 \\
\hline 8 & 3 & 4 & 4 & 4 & 4 & 4 & 6 & 4 & 4 & 1 & 5 & 3 \\
\hline 9 & 2 & 1 & 2 & 2 & 1 & 4 & 1 & 3 & 1 & 1 & 2 & 1 \\
\hline 10 & 5 & 5 & 4 & 4 & 4 & 4 & 4 & 6 & 4 & 3 & 4 & 3 \\
\hline 11 & 2 & 4 & 3 & 5 & 4 & 3 & 3 & 1 & 2 & 1 & 2 & 3 \\
\hline 12 & 3 & 4 & 3 & 4 & 6 & 3 & 2 & 1 & 6 & 5 & 4 & 2 \\
\hline 13 & 3 & 4 & 4 & 4 & 5 & 3 & 5 & 4 & 5 & 7 & 4 & 1 \\
\hline 14 & 4 & 5 & 4 & 3 & 2 & 5 & 3 & 3 & 3 & 7 & 3 & 4 \\
\hline 15 & 5 & 6 & 6 & 5 & 4 & 3 & 6 & 7 & 6 & 7 & 5 & 5 \\
\hline 16 & 2 & 1 & 2 & 3 & 1 & 1 & 1 & 1 & 1 & 1 & 2 & 2 \\
\hline 17 & 3 & 3 & 3 & 3 & 2 & 1 & 3 & 2 & 1 & 4 & 2 & 1 \\
\hline 18 & 5 & 5 & 3 & 4 & 3 & 1 & 2 & 7 & 2 & 6 & 2 & 2 \\
\hline 19 & 3 & 3 & 3 & 4 & 2 & 1 & 2 & 1 & 1 & 1 & 2 & 2 \\
\hline 20 & 2 & 2 & 3 & 5 & 3 & 1 & 4 & 4 & 3 & 3 & 2 & 3 \\
\hline
\end{tabular}

$\begin{array}{lllllllllllll}21 & 2 & 2 & 3 & 2 & 1 & 1 & 2 & 2 & 1 & 1 & 2 & 1 \\ 22 & 2 & 3 & 3 & 4 & 4 & 4 & 4 & 3 & 2 & 3 & 2 & 3 \\ 23 & 5 & 5 & 5 & 6 & 5 & 1 & 5 & 5 & 6 & 5 & 4 & 2 \\ 24 & 2 & 2 & 3 & 4 & 3 & 1 & 4 & 4 & 2 & 2 & 3 & 3 \\ 25 & 3 & 2 & 2 & 2 & 4 & 1 & 2 & 1 & 2 & 3 & 2 & 2 \\ 26 & 2 & 2 & 3 & 2 & 4 & 1 & 2 & 4 & 4 & 1 & 2 & 2 \\ 27 & 2 & 1 & 3 & 4 & 2 & 4 & 3 & 2 & 1 & 1 & 3 & 2 \\ 28 & 2 & 3 & 3 & 5 & 1 & 3 & 4 & 5 & 3 & 1 & 3 & 1 \\ 29 & 2 & 1 & 3 & 5 & 1 & 1 & 2 & 1 & 2 & 1 & 2 & 1 \\ 30 & 4 & 3 & 3 & 6 & 3 & 3 & 4 & 2 & 4 & 3 & 3 & 2\end{array}$

$\begin{array}{lllllllllllll}31 & 2 & 1 & 3 & 4 & 2 & 1 & 3 & 3 & 4 & 1 & 2 & 2 \\ 32 & 5 & 3 & 5 & 3 & 5 & 3 & 5 & 4 & 6 & 7 & 3 & 4 \\ 33 & 2 & 2 & 3 & 2 & 4 & 1 & 3 & 4 & 1 & 3 & 2 & 2 \\ 34 & 2 & 2 & 3 & 4 & 1 & 4 & 4 & 3 & 3 & 1 & 3 & 2 \\ 35 & 3 & 2 & 3 & 4 & 3 & 4 & 4 & 6 & 6 & 4 & 4 & 2 \\ 36 & 3 & 2 & 3 & 4 & 2 & 2 & 4 & 4 & 6 & 1 & 4 & 1 \\ 37 & 5 & 5 & 6 & 5 & 5 & 4 & 7 & 7 & 7 & 7 & 6 & 5 \\ 38 & 4 & 4 & 3 & 5 & 4 & 1 & 3 & 4 & 4 & 3 & 3 & 2 \\ 39 & 3 & 1 & 3 & 3 & 2 & 2 & 4 & 5 & 6 & 3 & 3 & 2 \\ 40 & 2 & 4 & 3 & 3 & 3 & 1 & 3 & 1 & 2 & 1 & 2 & 1\end{array}$

(Continued on next page) 
Appendix $\mathrm{H}$. (Continued)

\begin{tabular}{|c|c|c|c|c|c|c|c|c|c|c|c|c|}
\hline \multirow{2}{*}{$\begin{array}{c}\text { Item } \\
\text { number }\end{array}$} & \multicolumn{12}{|c|}{ Expert number } \\
\hline & 1 & 2 & 3 & 4 & 5 & 6 & 7 & 8 & 9 & 10 & 11 & 12 \\
\hline 41 & 5 & 4 & 5 & 5 & 6 & 1 & 5 & 2 & 3 & 6 & 6 & 4 \\
\hline 42 & 4 & 5 & 3 & 5 & 4 & 3 & 5 & 5 & 4 & 5 & 3 & 3 \\
\hline 43 & 6 & 5 & 4 & 6 & 5 & 3 & 4 & 6 & 4 & 4 & 4 & 4 \\
\hline 44 & 4 & 5 & 3 & 4 & 5 & 4 & 6 & 6 & 7 & 6 & 4 & 5 \\
\hline 45 & 3 & 2 & 3 & 4 & 5 & 2 & 4 & 5 & 4 & 6 & 3 & 2 \\
\hline 46 & 5 & 3 & 4 & 5 & 5 & 3 & 5 & 5 & 5 & 5 & 5 & 5 \\
\hline 47 & 3 & 4 & 6 & 5 & 6 & 1 & 3 & 1 & 3 & 6 & 4 & 3 \\
\hline 48 & 5 & 5 & 6 & 6 & 6 & 5 & 6 & 7 & 5 & 7 & 6 & 6 \\
\hline 49 & 4 & 2 & 3 & 6 & 3 & 2 & 4 & 5 & 5 & 6 & 3 & 3 \\
\hline 50 & 5 & 5 & 6 & 6 & 5 & 3 & 7 & 6 & 5 & 7 & 5 & 4 \\
\hline 51 & 4 & 7 & 2 & 3 & 2 & 1 & 3 & 2 & 1 & 1 & 3 & 2 \\
\hline 52 & 3 & 2 & 2 & 4 & 2 & 1 & 4 & 3 & 4 & 1 & 3 & 2 \\
\hline 53 & 5 & 4 & 5 & 5 & 4 & 3 & 5 & 6 & 5 & 7 & 6 & 3 \\
\hline 54 & 4 & 3 & 3 & 6 & 5 & 1 & 6 & 5 & 6 & 7 & 3 & 4 \\
\hline 55 & 3 & 5 & 6 & 6 & 6 & 4 & 6 & 2 & 4 & 6 & 6 & 4 \\
\hline 56 & 6 & 5 & 6 & 3 & 5 & 4 & 7 & 7 & 7 & 7 & 6 & 4 \\
\hline 57 & 2 & 4 & 2 & 3 & 2 & 3 & 3 & 3 & 2 & 4 & 2 & 2 \\
\hline 58 & 5 & 5 & 6 & 5 & 6 & 3 & 7 & 2 & 5 & 6 & 4 & 5 \\
\hline 59 & 5 & 4 & 2 & 5 & 6 & 1 & 4 & 5 & 3 & 6 & 3 & 3 \\
\hline 60 & 5 & 5 & 6 & 3 & 5 & 2 & 7 & 2 & 5 & 7 & 5 & 4 \\
\hline 61 & 2 & 3 & 2 & 3 & 2 & 1 & 2 & 1 & 1 & 3 & 2 & 1 \\
\hline 62 & 3 & 2 & 2 & 6 & 4 & 2 & 4 & 2 & 5 & 4 & 2 & 1 \\
\hline 63 & 5 & 6 & 6 & 3 & 5 & 4 & 6 & 1 & 4 & 6 & 4 & 3 \\
\hline 64 & 5 & 5 & 4 & 2 & 5 & 4 & 5 & 6 & 6 & 7 & 5 & 4 \\
\hline 65 & 2 & 2 & 2 & 3 & 2 & 1 & 3 & 1 & 1 & 4 & 2 & 1 \\
\hline 66 & 4 & 2 & 3 & 2 & 4 & 1 & 4 & 5 & 5 & 7 & 2 & 2 \\
\hline 67 & 2 & 3 & 3 & 2 & 4 & 1 & 2 & 2 & 2 & 4 & 3 & 1 \\
\hline
\end{tabular}


APPENDIX H

SUBJECTS' RESPONSES TO QUESTIONNAIRE

Women's Responses

\begin{tabular}{|c|c|c|c|c|c|c|c|c|c|c|c|c|c|c|c|c|c|c|}
\hline \multirow{2}{*}{$\begin{array}{c}\begin{array}{c}\text { Item } \\
\text { number }\end{array} \\
1\end{array}$} & \multicolumn{5}{|c|}{$\begin{array}{l}\text { Teenage bride- } \\
\text { Teenage groom }\end{array}$} & \multicolumn{5}{|c|}{$\begin{array}{l}\text { Teenage bride- } \\
\text { Adult groom }\end{array}$} & \multicolumn{4}{|c|}{$\begin{array}{l}\text { Adult bride- } \\
\text { Teenage groom }\end{array}$} & \multicolumn{4}{|c|}{$\begin{array}{l}\text { Adult bride- } \\
\text { Adult groom }\end{array}$} \\
\hline & 7 & 4 & 6 & 7 & 4 & 2 & 1 & 4 & 7 & 6 & 2 & 6 & 7 & 4 & 1 & 1 & 4 & 3 \\
\hline 2 & 2 & 2 & 1 & 1 & 1 & 1 & 1 & 2 & 2 & 4 & 1 & 1 & 4 & 1 & 1 & 1 & 1 & 4 \\
\hline 3 & 1 & 1 & 5 & 1 & 1 & 1 & 1 & 1 & 1 & 1 & 1 & 1 & 1 & 1 & 1 & 1 & 1 & 1 \\
\hline 4 & 1 & 1 & 1 & 1 & 1 & 1 & 1 & 1 & 1 & 4 & 1 & 1 & 1 & 1 & 1 & 1 & 1 & 1 \\
\hline 5 & 1 & 1 & 1 & 1 & 1 & 1 & 1 & 1 & 5 & 3 & 1 & 3 & 1 & 1 & 1 & 1 & 1 & 1 \\
\hline 6 & 1 & 3 & 4 & 1 & 7 & 2 & 1 & 3 & 2 & 2 & 1 & 1 & 7 & 1 & 2 & 3 & 3 & 1 \\
\hline 7 & 1 & 2 & 1 & 1 & 6 & 1 & 1 & 1 & 2 & 6 & 1 & 1 & 1 & 1 & 1 & 1 & 1 & 1 \\
\hline 8 & 3 & 2 & 5 & 1 & 1 & 3 & 1 & 1 & 4 & 7 & 1 & 1 & 1 & 3 & 1 & 3 & 4 & 3 \\
\hline 9 & 1 & 1 & 1 & 1 & 6 & 1 & 1 & 1 & 3 & 7 & 3 & 1 & 1 & 2 & 1 & 4 & 1 & 1 \\
\hline 10 & 1 & 1 & 1 & 1 & 1 & 1 & 1 & 1 & 3 & 3 & 1 & 1 & 1 & 1 & 1 & 1 & 1 & 1 \\
\hline 11 & 3 & 7 & 6 & 1 & 4 & 1 & 1 & 1 & 7 & 1 & 1 & 5 & 1 & 3 & 1 & 1 & 3 & 1 \\
\hline 12 & 1 & 1 & 1 & 1 & 3 & 1 & 1 & 1 & 3 & 2 & 1 & 1 & 1 & 1 & 1 & 1 & 1 & 1 \\
\hline 13 & 1 & 1 & 6 & 4 & 1 & 1 & 1 & 1 & 3 & 1 & 1 & 3 & 1 & 5 & 2 & 2 & 3 & 1 \\
\hline 14 & 1 & 1 & 3 & 1 & 1 & 1 & 1 & 1 & 2 & 1 & 1 & 1 & 1 & 1 & 1 & 1 & 2 & 1 \\
\hline 15 & 1 & 1 & 2 & 1 & 2 & 1 & 2 & 1 & 2 & 4 & 1 & 1 & 1 & 1 & 1 & 1 & 5 & 5 \\
\hline 16 & 1 & 1 & 3 & 1 & 1 & 1 & 1 & 1 & 1 & 6 & 1 & 1 & 1 & 1 & 1 & 1 & 1 & 2 \\
\hline 17 & 5 & 5 & 5 & 7 & 6 & 2 & 4 & 7 & 4 & 1 & 5 & 5 & 7 & 7 & 3 & 4 & 6 & 7 \\
\hline 18 & 1 & 3 & 2 & 1 & 1 & 1 & 1 & 1 & 4 & 1 & 1 & 1 & 1 & 5 & 1 & 1 & 1 & 3 \\
\hline 19 & 7 & 7 & 5 & 7 & 7 & 7 & 7 & 7 & 7 & 5 & 6 & 6 & 7 & 7 & 7 & 7 & 7 & 7 \\
\hline 20 & 1 & 1 & 4 & 1 & 1 & 1 & 1 & 2 & 1 & 6 & 1 & 1 & 1 & 1 & 3 & 2 & 1 & 2 \\
\hline 21 & 7 & 7 & 7 & 7 & 7 & 7 & 7 & 7 & 7 & 1 & 7 & 7 & 7 & 7 & 6 & 7 & 7 & 7 \\
\hline 22 & 7 & 6 & 5 & 7 & 7 & 5 & 6 & 7 & 6 & 1 & 4 & 6 & 4 & 7 & 4 & 3 & 7 & 7 \\
\hline 23 & 1 & 7 & 1 & 1 & 1 & 1 & 1 & 1 & 1 & 1 & 1 & 1 & 1 & 1 & 1 & 1 & 1 & 1 \\
\hline 24 & 3 & 4 & 4 & 5 & 1 & 5 & 2 & 2 & 6 & 6 & 1 & 1 & 1 & 6 & 1 & 2 & 1 & 2 \\
\hline 25 & 7 & 7 & 5 & 7 & 7 & 6 & 7 & 7 & 7 & 6 & 7 & 7 & 4 & 7 & 3 & 7 & 7 & 7 \\
\hline 26 & 1 & 3 & 5 & 1 & 1 & 1 & 1 & 1 & 2 & 6 & 1 & 3 & 4 & 5 & 1 & 2 & 1 & 3 \\
\hline 27 & 1 & 1 & 1 & 1 & 1 & 1 & 1 & 1 & 1 & 6 & 1 & 1 & 1 & 1 & 1 & 1 & 1 & 1 \\
\hline 28 & 1 & 3 & 3 & 1 & 1 & 1 & 1 & 1 & 3 & 6 & 1 & 1 & 4 & 2 & 1 & 2 & 1 & 2 \\
\hline 29 & 7 & 6 & 6 & 7 & 3 & 6 & 7 & 7 & 6 & 6 & 7 & 7 & 4 & 7 & 5 & 7 & 7 & 7 \\
\hline 30 & 7 & 6 & 6 & 7 & 1 & 6 & 3 & 6 & 6 & 6 & 3 & 4 & 4 & 7 & 7 & 7 & 5 & 4 \\
\hline
\end{tabular}




\section{Men's Responses}

\begin{tabular}{|c|c|c|c|c|c|c|c|c|c|c|c|c|c|c|c|c|c|c|}
\hline \multirow{2}{*}{$\begin{array}{c}\begin{array}{c}\text { Item } \\
\text { number }\end{array} \\
1\end{array}$} & \multicolumn{4}{|c|}{$\begin{array}{l}\text { Teenage groom- } \\
\text { Teenage bride }\end{array}$} & \multicolumn{5}{|c|}{$\begin{array}{l}\text { Teenage groom- } \\
\text { Adult bride }\end{array}$} & \multicolumn{4}{|c|}{$\begin{array}{l}\text { Adult groom- } \\
\text { Teenage bride }\end{array}$} & \multicolumn{5}{|c|}{$\begin{array}{l}\text { Adult groom- } \\
\text { Adult bride }\end{array}$} \\
\hline & 3 & 7 & 3 & 3 & 2 & 5 & 4 & 5 & 7 & 5 & 5 & 5 & 7 & 7 & 6 & 7 & 7 & 7 \\
\hline 2 & 1 & 1 & 1 & 2 & 2 & 1 & 1 & 1 & 1 & 3 & 1 & 1 & 4 & 1 & 6 & 1 & 1 & 1 \\
\hline 3 & 1 & 1 & 1 & 1 & 1 & 1 & 1 & 1 & 1 & 1 & 1 & 1 & 1 & 1 & 1 & 1 & 1 & 1 \\
\hline 4 & 1 & 1 & 1 & 1 & 1 & 1 & 1 & 3 & 1 & 1 & 1 & 5 & 2 & 1 & 1 & 1 & 1 & 1 \\
\hline 5 & 1 & 1 & 1 & 1 & 1 & 1 & 1 & 2 & 1 & 1 & 1 & 1 & 1 & 1 & 1 & 1 & 1 & 1 \\
\hline 6 & 2 & 1 & 1 & 1 & 1 & 1 & 6 & 5 & 1 & 1 & 5 & 1 & 1 & 3 & 1 & 1 & 1 & 1 \\
\hline 7 & 1 & 1 & 1 & 1 & 1 & 1 & 1 & 1 & 1 & 1 & 1 & 1 & 1 & 1 & 1 & 1 & 1 & 1 \\
\hline 8 & 3 & 1 & 3 & 1 & 1 & 1 & 4 & 7 & 1 & 5 & 4 & 5 & 2 & 1 & 5 & 3 & 1 & 1 \\
\hline 9 & 1 & 1 & 1 & 1 & 1 & 3 & 4 & 1 & 1 & 3 & 1 & 1 & 5 & 3 & 1 & 1 & 1 & 1 \\
\hline 10 & 1 & 1 & 1 & 1 & 1 & 3 & 1 & 1 & 1 & 1 & 1 & 1 & 2 & 1 & 1 & 1 & 1 & 1 \\
\hline 11 & 1 & 7 & 2 & 1 & 1 & 5 & 1 & 6 & 6 & 7 & 4 & 5 & 5 & 5 & 5 & 4 & 7 & 7 \\
\hline 12 & 1 & 1 & 3 & 1 & 1 & 1 & 1 & 1 & 1 & 1 & 1 & 1 & 1 & 1 & 1 & 1 & 1 & 1 \\
\hline 13 & 3 & 1 & 2 & 1 & 4 & 1 & 1 & 5 & 1 & 1 & 1 & 1 & 1 & 3 & 1 & 1 & 1 & 1 \\
\hline 14 & 1 & 1 & 2 & 1 & 1 & 1 & 1 & 3 & 1 & 1 & 1 & 1 & 1 & 1 & 1 & 1 & 1 & 1 \\
\hline 15 & 1 & 1 & 2. & 4 & 4 & 5 & 1 & 4 & 1 & 1 & 3 & 5 & 1 & 4 & 2 & 1 & 1 & 4 \\
\hline 16 & 1 & 1 & 2 & 2 & 1 & 3 & 1 & 1 & 1 & 1 & 1 & 1 & 1 & 1 & 1 & 1 & 1 & 1 \\
\hline 17 & 3 & 7 & 3 & 5 & 7 & 5 & 4 & 5 & 4 & 4 & 7 & 5 & 7 & 5 & 5 & 7 & 6 & 6 \\
\hline 18 & 1 & 1 & 2 & 1 & 1 & 1 & 1 & 1 & 1 & 1 & 2 & 1 & 1 & 1 & 1 & 1 & 1 & 1 \\
\hline 19 & 5 & 7 & 5 & 6 & 7 & 7 & 7 & 7 & 1 & 5 & 7 & 7 & 7 & 7 & 7 & 7 & 7 & 5 \\
\hline 20 & 1 & 1 & 2 & 1 & 1 & 3 & 1 & 5 & 1 & 1 & 1 & 1 & 1 & 1 & 1 & 1 & 1 & 1 \\
\hline 21 & 6 & 7 & 7 & 7 & 7 & 7 & 7 & 7 & 7 & 7 & 7 & 5 & 7 & 7 & 7 & 7 & 7 & 7 \\
\hline 22 & 7 & 7 & 4 & 5 & 5 & 5 & 5 & 7 & 1 & 3 & 7 & 5 & 6 & 5 & 7 & 7 & 1 & 5 \\
\hline 23 & 1 & 1 & 2 & 1 & 1 & 1 & 3 & 1 & 1 & 1 & 1 & 1 & 1 & 1 & 7 & 1 & 1 & 1 \\
\hline 24 & 1 & 1 & 2 & 4 & 6 & 5 & 3 & 3 & 1 & 1 & 6 & 5 & 5 & 1 & 4 & 4 & 7 & 5 \\
\hline 25 & 6 & 7 & 6 & 6 & 7 & 7 & 7 & 7 & 7 & 5 & 7 & 4 & 7 & 6 & 7 & 7 & 7 & 7 \\
\hline 26 & 1 & 1 & 2 & 2 & 1 & 1 & 1 & 2 & 1 & 1 & 2 & 1 & 1 & 1 & 3 & 1 & 1 & 1 \\
\hline 27 & 1 & 1 & 1 & 1 & 1 & 1 & 1 & 2 & 1 & 1 & 1 & 1 & 1 & 1 & 1 & 1 & 1 & 1 \\
\hline 28 & 1 & 1 & 2 & 3 & 1 & 1 & 1 & 1 & 1 & 1 & 1 & 1 & 1 & 1 & 1 & 1 & 1 & 1 \\
\hline 29 & 4 & 7 & 6 & 7 & 7 & 5 & 6 & 7 & 6 & 3 & 7 & 5 & 7 & 6 & 7 & 7 & 7 & 6 \\
\hline 30 & 1 & 7 & 3 & 6 & 4 & 5 & 3 & 5 & 1 & 3 & 6 & 5 & 7 & 7 & 5 & 7 & 7 & 4 \\
\hline
\end{tabular}


APPENDEX I

RESPONSE PATTERN OF SUBJECTS TO ITEMS

\begin{tabular}{|c|c|c|c|c|c|c|c|}
\hline $\begin{array}{c}\text { Item } \\
\text { number }\end{array}$ & $\begin{array}{c}\begin{array}{c}\text { Did not } \\
\text { consider } \\
1\end{array} \\
\end{array}$ & 2 & 3 & 4 & 5 & 6 & $\begin{array}{c}\text { Strongly } \\
\text { considered } \\
7 \\
\end{array}$ \\
\hline 1 & 3 & 3 & 4 & 6 & 5 & 4 & 11 \\
\hline 2 & 24 & 6 & 1 & 4 & & 1 & \\
\hline 3 & 35 & & & & 1 & & \\
\hline 4 & 32 & 1 & 1 & 1 & 1 & & \\
\hline 5 & 32 & 1 & 2 & & 1 & & \\
\hline 6 & 20 & 5 & 5 & 1 & 2 & 1 & 2 \\
\hline 7 & 32 & 2 & & & & 2 & \\
\hline 8 & 16 & 2 & 8 & 4 & 4 & & 2 \\
\hline 9 & 25 & 1 & 5 & 2 & 1 & 1 & 1 \\
\hline 10 & 32 & 1 & 3 & & & & \\
\hline 11 & 14 & 1 & 3 & 3 & 6 & 3 & 6 \\
\hline 12 & 32 & 1 & 3 & & & & \\
\hline 13 & 23 & 3 & 5 & 2 & 2 & 1 & \\
\hline 14 & 31 & 3 & 2 & & & & \\
\hline 15 & 19 & 6 & 1 & 6 & 4 & & \\
\hline 16 & 30 & 3 & 2 & & & 1 & \\
\hline 17 & 1 & 1 & 3 & 6 & 11 & 4 & 10 \\
\hline 18 & 29 & 3 & 2 & 1 & 1 & & \\
\hline 19 & 1 & & & & 6 & 3 & 26 \\
\hline 20 & 28 & 3 & 2 & 1 & 1 & 1 & \\
\hline 21 & 1 & & & & 1 & 2 & 32 \\
\hline 22 & 3 & & 2 & 4 & 9 & 5 & 13 \\
\hline 23 & 32 & 1 & 1 & & & & 2 \\
\hline 24 & 11 & 5 & 3 & 5 & 6 & 5 & 1 \\
\hline 25 & & & 1 & 2 & 2 & 6 & 25 \\
\hline 26 & 22 & 6 & 4 & 1 & 2 & 1 & \\
\hline 27 & 34 & 1 & & & & 1 & \\
\hline 28 & 26 & 4 & 4 & 1 & & 1 & \\
\hline 29 & & & 2 & 2 & 3 & 10 & 19 \\
\hline 30 & 3 & & 5 & 5 & 5 & 8 & 10 \\
\hline
\end{tabular}

This chart indicates the spread of responses given by subjects to each question. The numbers indicate the number of subjects, on each particular question, who chose a particular response. 
A PPENDIX J

EMOTIONAL MATURITY SCORES

\begin{tabular}{cccc}
$\begin{array}{c}\text { Teenage Bride- } \\
\text { Teenage Groom }\end{array}$ & $\begin{array}{c}\text { Teenage Bride- } \\
\text { Adult Groom }\end{array}$ & $\begin{array}{c}\text { Adult Bride- } \\
\text { Teenage Groom }\end{array}$ & $\begin{array}{c}\text { Adult Bride- } \\
\text { Adult Groom }\end{array}$ \\
\cline { 2 - 4 } 42 & 41 & 46 & 39 \\
43 & 46 & 48 & 43 \\
49 & 52 & 49 & 44 \\
60 & 72 & 56 & 54 \\
Teenage Groom- & Teenage Groom- & Adult Groom- & Adult Groom- \\
Teenage Bride & Adult Bride & Teenage Bride & Adult Bride \\
\hline 37 & 33 & 36 & 37 \\
40 & 38 & 37 & 42 \\
50 & 42 & 43 & 44 \\
51 & 45 & 45 & 44
\end{tabular}

This table shows the emotional maturity scores for the 36 subjects. The scores are ranked according to the degree of maturity. The smaller the number, the less the discrepancy from the experts and thus the more "mature" the subject is. 